\title{
Fluvial geochemistry of Subarnarekha River basin, India
}

\author{
Abhay Kumar Singh*, Soma Giri and Aaditya Chaturvedi \\ Natural Resource and Environmental Management Division, CSIR - Central Institute of Mining \\ and Fuel Research, Barwa Road, Dhanbad 826 015, India. \\ ${ }^{*}$ Corresponding author.e-mail: singhak.cimfr@gmail.com
}

MS received 25 July 2017; revised 30 January 2018; accepted 12 March 2018; published online 26 October 2018

The fluvial geochemistry of the Subarnarekha River and its major tributaries has been studied on a seasonal basis in order to assess the geochemical processes that explain the water composition and estimate solute fluxes. The analytical results show the mildly acidic to alkaline nature of the Subarnarekha River water and the dominance of $\mathrm{Ca}^{2+}$ and $\mathrm{Na}^{+}$in cationic and $\mathrm{HCO}_{3}^{-}$and $\mathrm{Cl}^{-}$in anionic composition. Minimum ionic concentration during the monsoon and maximum concentration in the pre-monsoon seasons reflect concentrating effects due to decrease in the river discharge and increase in the base flow contribution during the pre-monsoon and dilution effects of atmospheric precipitation in the monsoon season. The solute acquisition processes are mainly controlled by weathering of rocks, with minor contribution from marine and anthropogenic sources. Higher contribution of alkaline earth $\left(\mathrm{Ca}^{2+}+\mathrm{Mg}^{2+}\right)$ to the total cations $\left(\mathrm{TZ}^{+}\right)$and high $\left(\mathrm{Na}^{+}+\mathrm{K}^{+}\right) / \mathrm{Cl}^{-},\left(\mathrm{Na}^{+}+\mathrm{K}^{+}\right) / \mathrm{TZ}^{+}$, $\mathrm{HCO}_{3}^{-} /\left(\mathrm{SO}_{4}^{2-}+\mathrm{Cl}^{-}\right)$and low $\left(\mathrm{Ca}^{2+}+\mathrm{Mg}^{2+}\right) /\left(\mathrm{Na}^{+}+\mathrm{K}^{+}\right)$equivalent ratios suggest that the Subarnarekha River water is under the combined influence of carbonate and silicate weathering. The river water is undersaturated with respect to dolomite and calcite during the post-monsoon and monsoon seasons and oversaturated in the pre-monsoon season. The $\mathrm{pH}-\log \mathrm{H}_{4} \mathrm{SiO}_{4}$ stability diagram demonstrates that the water chemistry is in equilibrium with the kaolinite. The Subarnarekha River annually delivered $1.477 \times 10^{6}$ ton of dissolved loads to the Bay of Bengal, with an estimated chemical denudation rate of 77 ton $\mathrm{km}^{-2} \mathrm{yr}^{-1}$. Sodium adsorption ratio, residual sodium carbonate and per cent sodium values placed the studied river water in the 'excellent to good quality' category and it can be safely used for irrigation.

Keywords. Subarnarekha River basin; weathering; solute acquisition; dissolved flux; saturation index; water quality.

\section{Introduction}

Water is the most essential natural resource for sustaining all forms of life, food production, economic development and general well-being. Water is also one of the most manageable natural resources as it can be diverted, transported, stored and recycled. India accounts for $2.4 \%$ of the global land and $4 \%$ of the world water resources, but it has to support $16 \%$ of the world's human and $20 \%$ of livestock populations (Kumar et al. 2005). Rivers are the major source of fresh water for agricultural and industrial usage. River processes form a major link in the geochemical cycle and the hydro-chemical study of river basins reveals the nature of weathering at a basin scale and helps 
in understanding the exogenic cycling of elements in the continent-river-ocean system. Nearly $90 \%$ of the natural weathered as well as man-made materials that are transported in both dissolved and particulate phases are delivered to the oceans by rivers (Meybeck 1987, 2003). The quantification of the major-ion composition of river water has broad implications in assessing the hydrogeological characteristics; weathering processes, water quality type and rainfall chemistry (Drever 1988; Gaillardet et al. 1999; Brennan and Lowenstein 2002). In addition, information on river water chemistry is essential to assess the water quality for domestic, agricultural and industrial uses and useful in environmental impact assessment and pollution control. India is gifted with a river system comprising more than 20 major rivers with several smaller river basins and its tributaries. Many of these rivers are perennial and some of them are seasonal (Rao 1975). The rivers of India drain a total area of about $3.1 \times 10^{6} \mathrm{~km}^{2}$ and annually discharge $1650 \mathrm{~km}^{3}$ of water, accounting for $4.5 \%$ of the global river discharge (Krishnaswami and Singh 2005). The hydrological cycle in most of the Indian river basins is being modified quantitatively and qualitatively as a result of developmental activities such as construction of dams and reservoirs; land use change; indiscriminate disposal of anthropogenic, industrial and mining wastes; unplanned application of agrochemicals and discharges of improperly treated sewage/industrial effluents (Chakrapani and Subramanian 1990; Ramanathan et al. 1994; Singh and Hasnain 1999; Subramanian 2000).

Previous studies have revealed the major-ion chemistry of some of the world's large- and medium-sized river systems including the Amazon (Gibbs 1972; Stallard and Edmond 1983, 1987; Gaillardet et al. 1997), Orinoco (Nemeth et al. 1982), Mackenzie (Reeder et al. 1972), Mississippi (Presley et al. 1980), Mekong (Carbonnel and Meybeck 1975), Changjiang and Huanghe (Hu et al. 1982; Zhang et al. 1990, 1995; Chen et al. 2002), Ganges-Brahmaputra (Abbas and Subramanian 1984; Sarin et al. 1989; Galy and France-Lanord 1999), Godavari (Biksham and Subramanian 1988; Jha et al. 2009), Krishna (Ramesh and Subramanian 1988; Das et al. 2005), Cauvery (Ramanathan et al. 1994; Pattanaik et al. 2013), Mahanadi (Chakrapani and Subramanian 1990); Damodar (Singh and Hasnain 1999) and Mahi (Sharma et al. 2012). These extensive studies not only reported the signatures of river systems responding to natural processes, such as atmospheric precipitation and chemical weathering, but also detected the significant signatures responding to human activities. The chemical composition of river water is determined by several factors such as relief and altitude of the catchment, tectono-climatic setup, rainfall quantity and quality, bedrock geology, soil and vegetation cover, biological and anthropogenic activities in the drainage basin (Berner and Berner 1987; Stallard and Edmond 1987; Rajamani et al. 2009). In comparison to large rivers, the smaller rivers invariably flow in less diverse geological terrains, having limited tectono-climatic variations and the effect of human interventions could be better constrained in a smaller river basin. The present study deals with the fluvial geochemistry of the Subarnarekha River basin - a moderate size rainfed river of eastern India flowing through India's important mining and industrial belt. This study aims to characterise the major-ion chemistry and evaluates weathering and solute acquisition processes and anthropogenic influences on the surface water quality of the Subarnarekha River. This study also envisages the seasonal and downstream compositional changes, dissolved fluxes and suitability of surface water resources for irrigation uses.

\section{Subarnarekha River basin}

The Subarnarekha is a moderate sized river basin, extending over $19,296 \mathrm{~km}^{2}$ and covering $0.6 \%$ of the geographical area of India. The total annual yield of water flowing within the basins is in the order of 7940 million $\mathrm{m}^{2}$ (CBPCWP 1986). It is a rain-fed river that rises from a series of contact springs located near the Nagri village $\left(23^{\circ} 18^{\prime} \mathrm{N}, 85^{\circ} 11^{\prime} \mathrm{E}\right)$ at an elevation of $740 \mathrm{~m}$ on the Ranchi Plateau in Chhota Nagpur highland (figure 1). The Subarnarekha empties its enormous volume of water and sediment load into the Bay of Bengal after its $395 \mathrm{~km}$ long journey from its source at Nagri village to its mouth near Kirtania port $\left(21^{\circ} 33^{\prime} 18^{\prime \prime} \mathrm{N}, 87^{\circ} 23^{\prime} 31^{\prime \prime} \mathrm{E}\right)$. Out of its total length of $395 \mathrm{~km}, 269 \mathrm{~km}$ are in Jharkhand, $64 \mathrm{~km}$ in West Bengal and $62 \mathrm{~km}$ in Odissa states. The Subarnarekha is a very important river to satisfy the irrigation, industrial and municipal water demands of these three states. Raru, Kanchi, Karkari, Kharkai and Dulung are the major tributaries of the Subarnarekha River. 


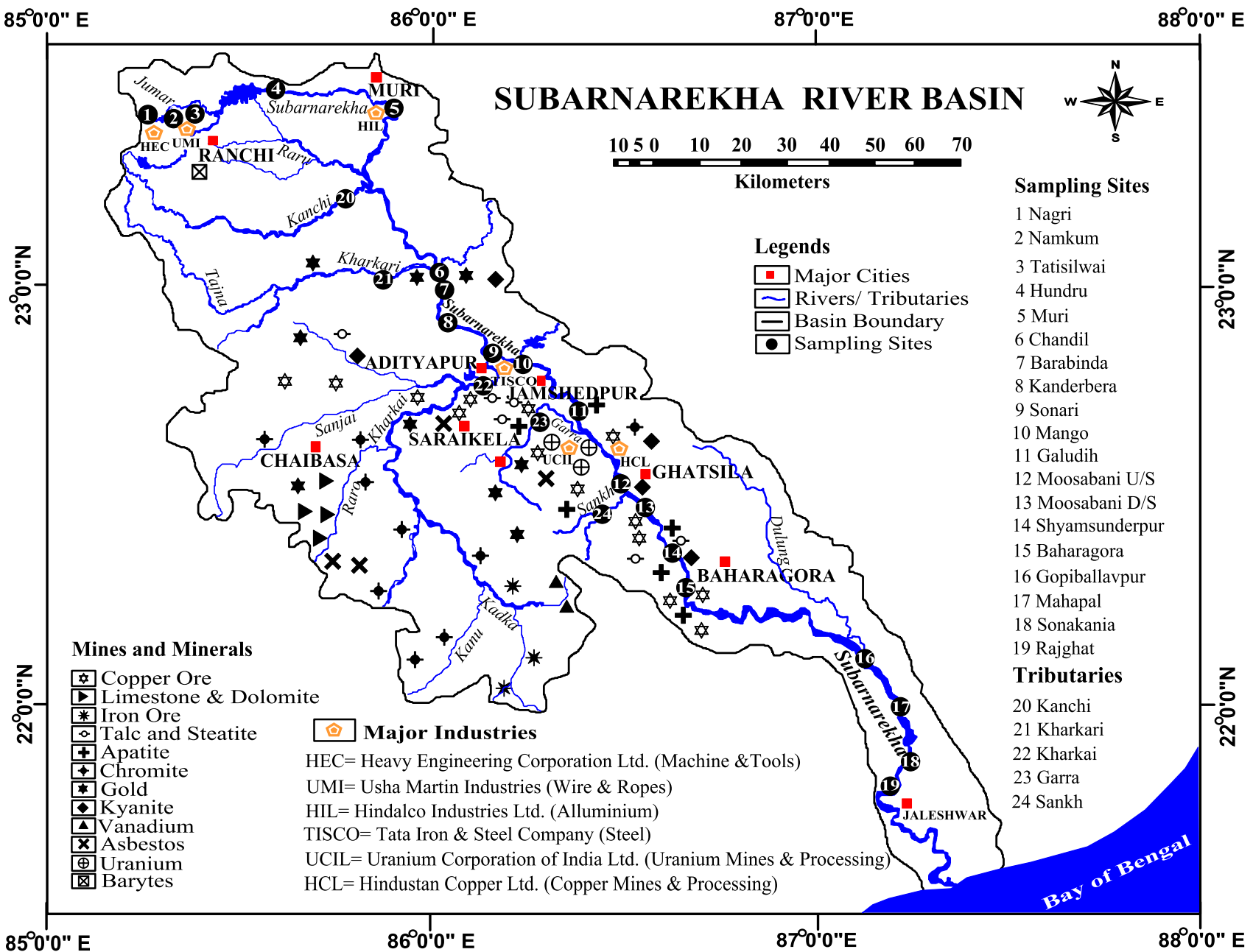

Figure 1. Location map of Subarnarekha River basin showing sampling locations, major mines, minerals and industrial zones.

The major part of the Subarnarekha basin lies on the Indian Shield, where the ancient Precambrian igneous and metamorphic rocks are exposed. In the lower reaches of the basin, the younger geological formation such as Tertiary Gravels, Pleistocene Alluvium and Recent Alluvium are exposed. Pelitic schist, calc-magnesium metasediments, ortho-amphibolites, tonalite-trondhjemite, banded iron formation, mafic lavas, phyllites, shales, metapellites, quartzites, soda-granites, granitic-gneiss, dolerite dyke swarms and gravels are the major litho units associated with the geological formations of the basin. The Subarnarekha basin is rich in mineral resources mainly comprising ores of metals such as copper, iron, uranium, chromium, gold, and vanadium and non-metals such as kyanite, asbestos, barytes, apatite, china clay, talc, limestone, dolomite and building stones (figure 1). The basin is studded with a large number of mineral-based industries and mines both working and abandoned with the attendant problems of environmental hazard. Heavy Engineering Corporation (HEC), Usha Martin Industries, Steel Authority of India (SAIL), Hindalco Industries Ltd., Tata Steel and Iron Company, Hindustan Copper Ltd. (HCL) and Uranium Corporation of India (UCIL) are the major industrial units in the basin.

The Subarnarekha basin is dominated by humid tropical climate with hot summers and mild winters. The mean monthly temperature varies from $40.5^{\circ} \mathrm{C}$ in May to $9.0^{\circ} \mathrm{C}$ in December. The mean annual rainfall in the basin is $\sim 1400 \mathrm{~mm}$. The rainfall distribution is not uniform and 85-95\% of the annual precipitation and about $82 \%$ of the total annual flow actually occurs over only four wet months (June-September), while in the remaining part of the year, the Subarnarekha River and its tributaries run almost dry. Agricultural land accounts for $62 \%$ of the total basin area 


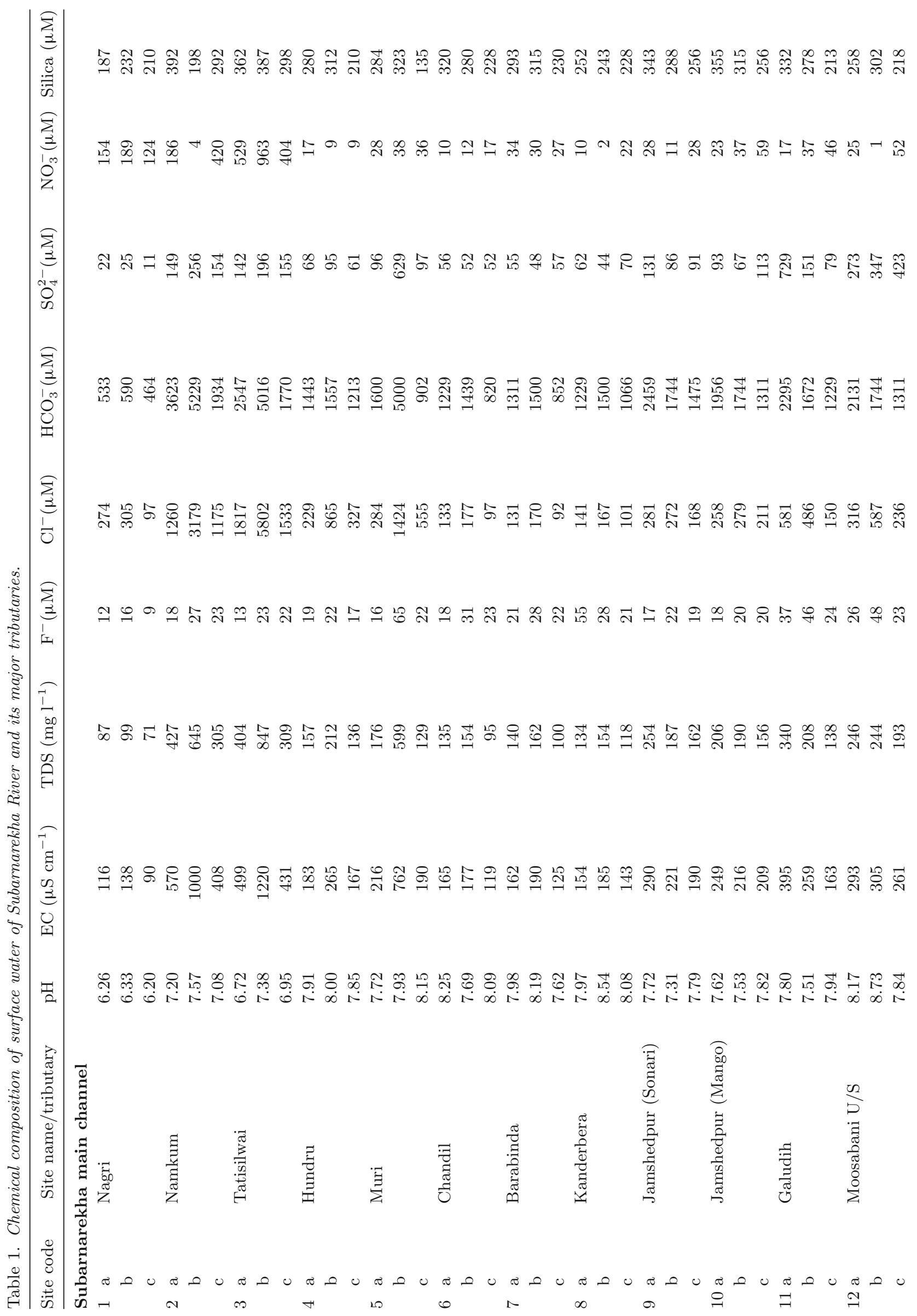




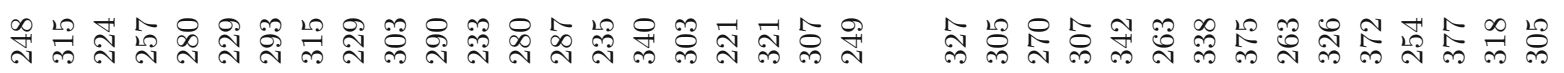

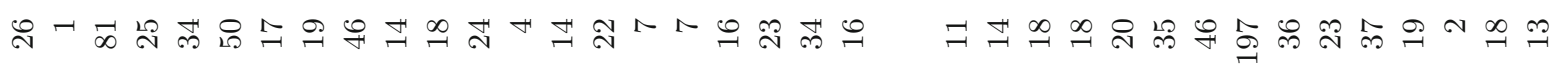

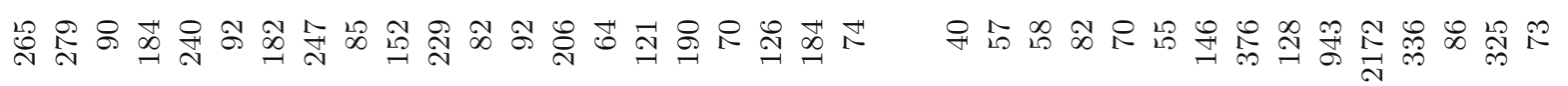

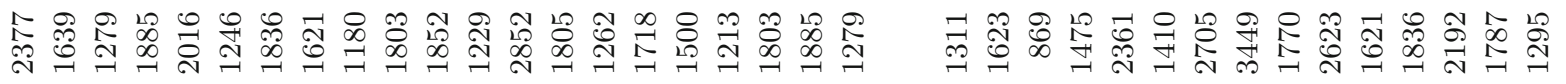

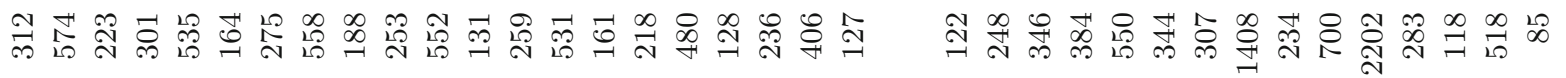

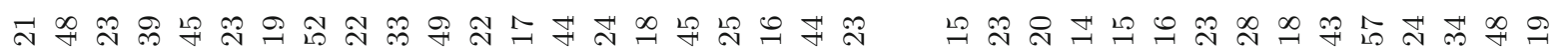

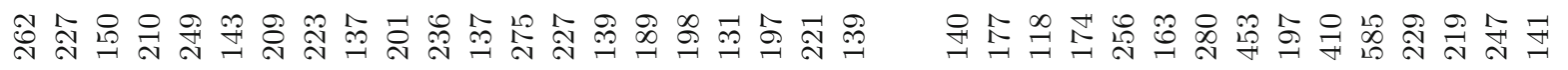

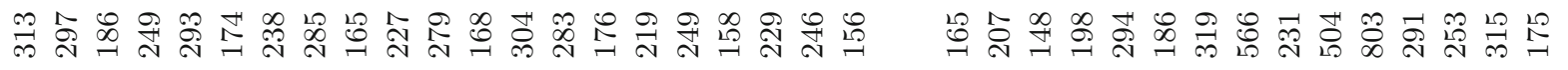

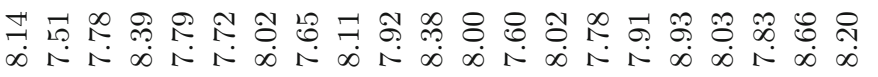

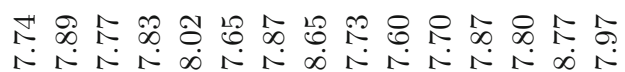

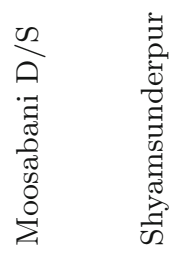
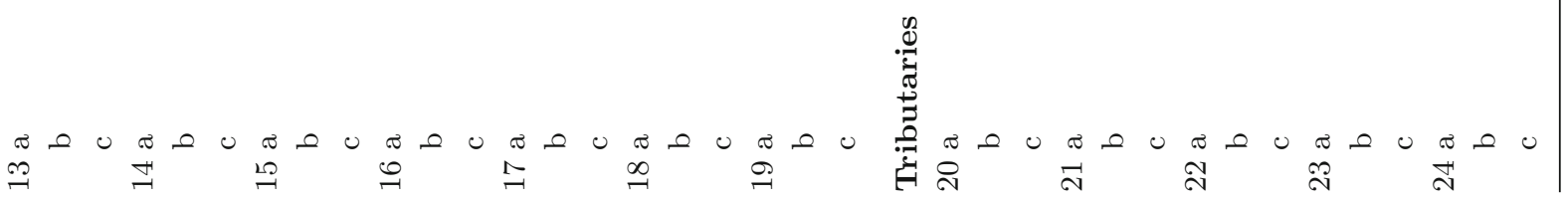


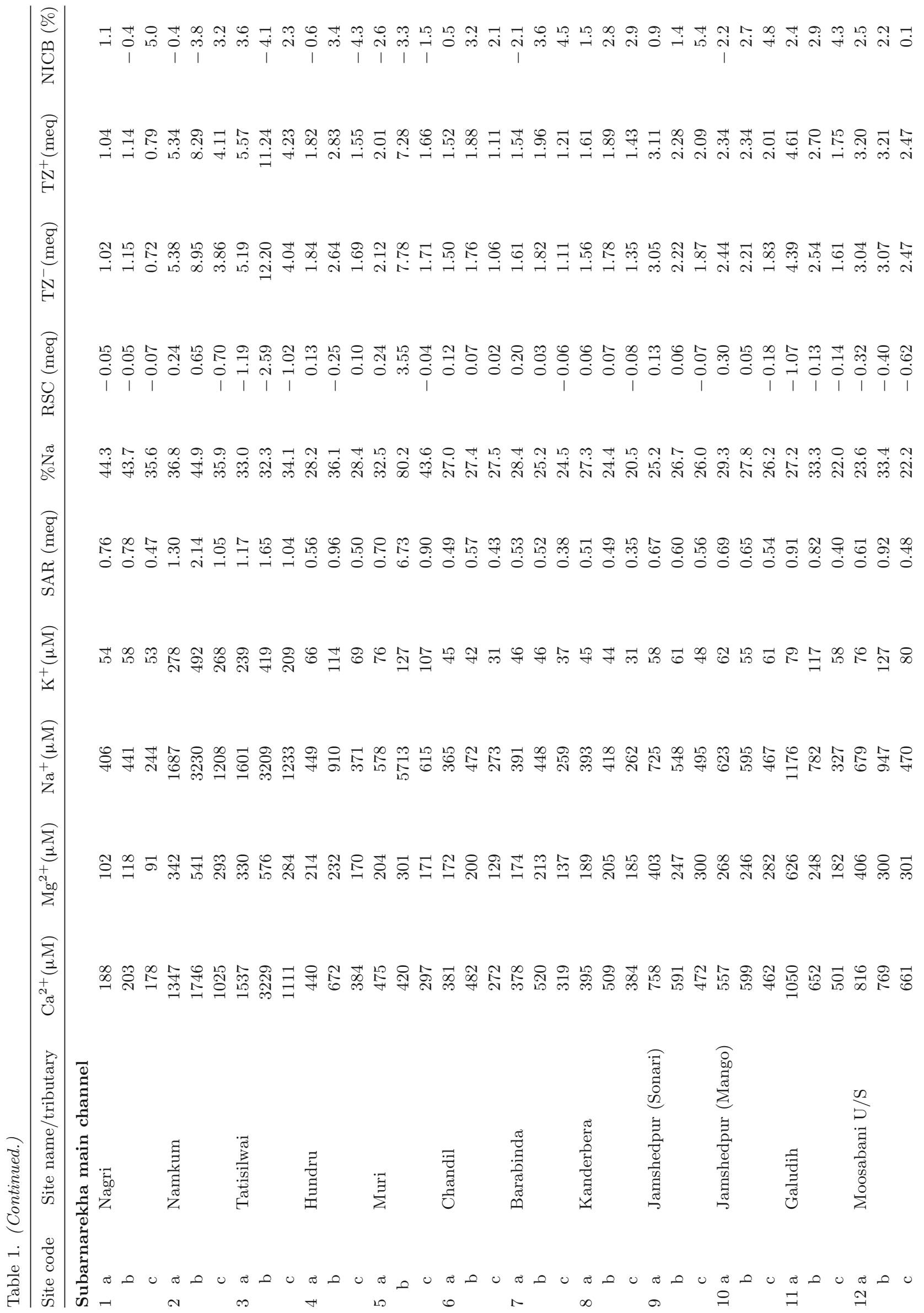


Ғ

मे

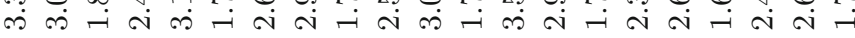

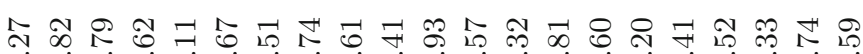
ஸे

虽

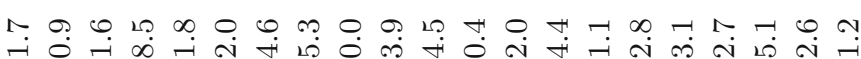
ப்

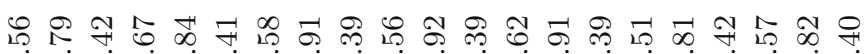

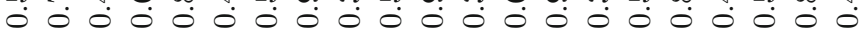

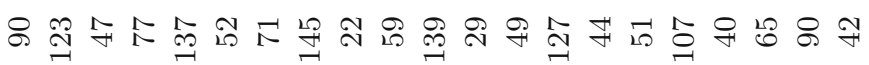

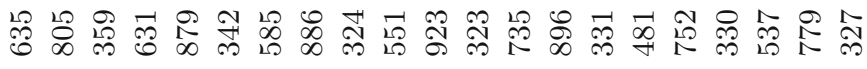

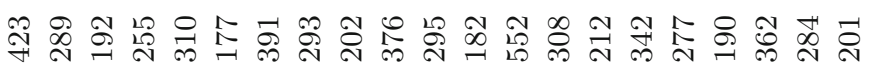

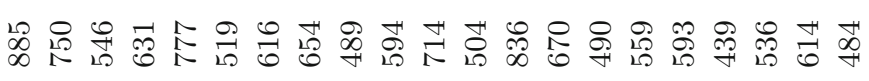

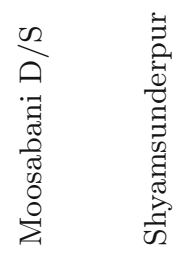

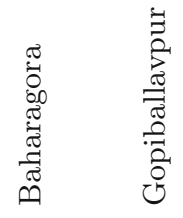

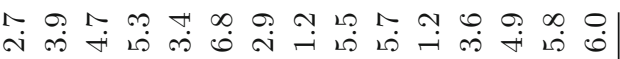

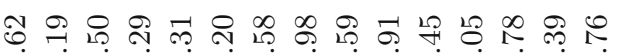

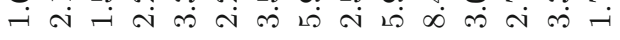

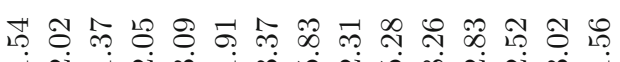
-

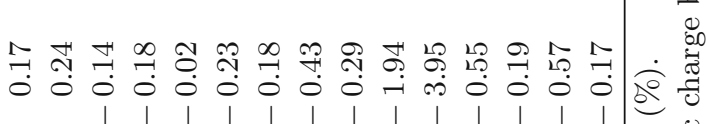

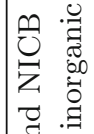

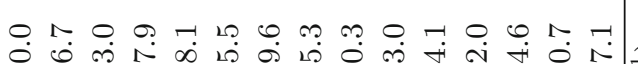

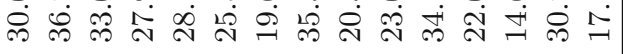
总

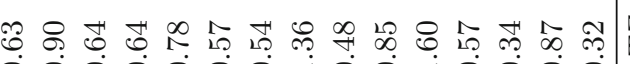

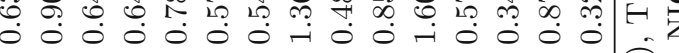
胥. 은 䣸

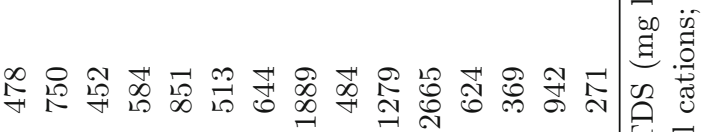

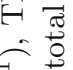

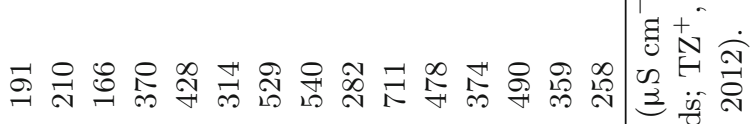

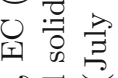
证

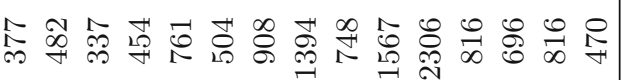

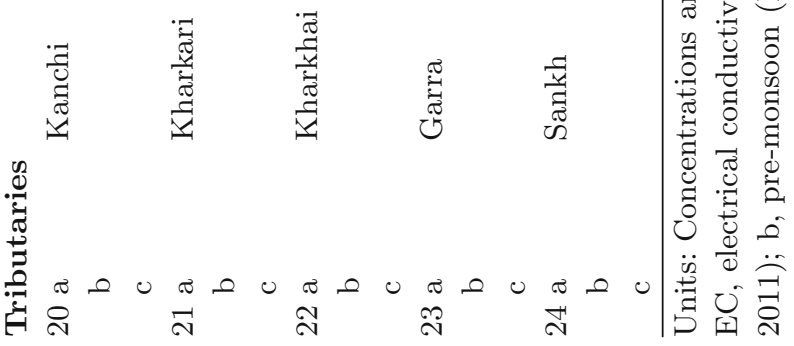


and nearly $31 \%$ of the area is devoted to forests. A number of dams/reservoirs (Getasuld, Hatia, Chandil, Galudih) have been constructed on the Subarnarekha and its tributaries mainly for the purpose of electricity generation, flood control and irrigation.

\section{Methodology}

Seventy-two water samples were collected from 24 sites along the Subarnarekha River and its major tributaries during the post-monsoon (September 2011), pre-monsoon (May 2012) and monsoon (July 2012) seasons (figure 1). The sampling seasons were selected according to the hydrological regime in the basin. The samples were mostly collected from the middle of the river, either from the bridge or with the help of a boat to avoid local heterogeneity and possible human influence near the river banks. Water samples were collected in the pre-washed narrow mouth 1-1 high-density polyethylene bottles. Electrical conductivity (EC) and $\mathrm{pH}$ values were measured in the field using a portable conductivity and $\mathrm{pH}$ meter after recalibration with the standard buffer solutions. The water samples were filtered through $0.45 \mu \mathrm{m}$ Millipore membrane filter to separate the suspended particulates. The concentration of bicarbonate $\left(\mathrm{HCO}_{3}^{-}\right)$and dissolved silica $\left(\mathrm{SiO}_{2}\right)$ were determined by acid titration and molybdosilicate methods, respectively (APHA 1998). The concentration of major $\mathrm{F}^{-}, \mathrm{Cl}^{-}, \mathrm{SO}_{4}^{2-}$ and $\mathrm{NO}_{3}^{-}$were analysed by Dionex ion chromatograph (DX-120) using anions AS12A/AG12 columns. The major cations $\left(\mathrm{Ca}^{2+}, \mathrm{Mg}^{2+}, \mathrm{Na}^{+}, \mathrm{K}^{+}\right)$were determined by atomic absorption spectrophotometer (Varian $680 \mathrm{FS}$ ) in flame mode. Three replicates were run for each sample and the instrument was recalibrated after every 15 samples analysis. An overall precision, expressed as per cent relative standard deviation, was obtained below $5 \%$ for the entire samples. Total cations $\left(\mathrm{TZ}^{+}\right)$and anions $\left(\mathrm{TZ}^{-}\right)$ are coupled by the relation $\mathrm{TZ}^{+}=0.947 \times \mathrm{TZ}^{-} \pm$ 0.237 with a correlation coefficient of 0.989 and the normalised inorganic charge balance (NICB) is within $\pm 10 \%$ (table 1 ). USGS hydrogeochemical software (PHREEQC) is used for the estimation of saturation index values of carbonate mineral phases (Parkhurst and Appelo 1999). Aquachem and Grapher software of Waterloo Hydrologic have been used for Piper diagram and other graphical presentation.
Water quality parameters such as sodium adsorption ratio (SAR), per cent sodium (\% Na) and residual sodium carbonate (RSC) were computed to assess the suitability of the Subarnarekha River basin water for irrigation by the following equations:

$$
\begin{aligned}
& \mathrm{SAR}=\mathrm{Na}^{+} / \sqrt{\left(\mathrm{Ca}^{2+}+\mathrm{Mg}^{2+}\right) / 2}, \\
& \% \mathrm{Na}=\mathrm{Na}+\mathrm{K} /(\mathrm{Ca}+\mathrm{Mg}+\mathrm{Na}+\mathrm{K}) \times 100, \\
& \mathrm{RSC}=\left(\mathrm{CO}_{3}^{2-}+\mathrm{HCO}_{3}^{-}\right)-\left(\mathrm{Ca}^{2+}+\mathrm{Mg}^{2+}\right) .
\end{aligned}
$$

(All ionic concentrations used for the calculation are expressed in meq $\mathrm{l}^{-1}$.)

\section{Results and discussion}

\subsection{Fluvial geochemistry}

The analytical results of surface water samples of the Subarnarekha River and its major tributaries during the post-monsoon, pre-monsoon and monsoon seasons are given in table 1 . Table 2 shows the range and average concentration of the measured parameters and ionic ratios in the Subarnarekha River water during the post-monsoon, pre-monsoon and monsoon seasons.

The $\mathrm{pH}$ of the Subarnarekha River water varied from 6.20 (mildly acidic) to 8.93 (alkaline), with most samples falling within a range of 7.0 8.0. The $\mathrm{pH}$ was slightly higher during the lean flow pre-monsoon (avg. 7.95) period as compared to the high flow regimes of monsoon (7.74) and post-monsoon (7.75). The water was slightly acidic in nature at the Nagri site, which might be due to comparatively more organic loading near the origin site of the Subarnarekha River. EC varied from 116 to $570 \mu \mathrm{S} \mathrm{cm} \mathrm{cm}^{-1}$ in post-monsoon, 138 to $1220 \mu \mathrm{S} \mathrm{cm}{ }^{-1}$ in pre-monsoon and 90 to $431 \mu \mathrm{S} \mathrm{cm}^{-1}$ during the monsoon season. On an average, the lowest EC is observed during the monsoon $\left(196 \mu \mathrm{S} \mathrm{cm}^{-1}\right)$ and the highest in the premonsoon $\left(377 \mu \mathrm{S} \mathrm{cm}^{-1}\right)$, while the post-monsoon season is characterised by an intermediate value $\left(271 \mu \mathrm{S} \mathrm{cm}^{-1}\right)$. Total dissolved solids (TDS) in the Subarnarekha basin water ranged from 71 to $847 \mathrm{mg} \mathrm{l}^{-1}$ with an average concentration value of $225 \mathrm{mg} \mathrm{l}^{-1}$. The low TDS value is observed near the river origin site at Nagri village and it increases randomly at the downstream sites. Like EC, TDS concentration was relatively higher 


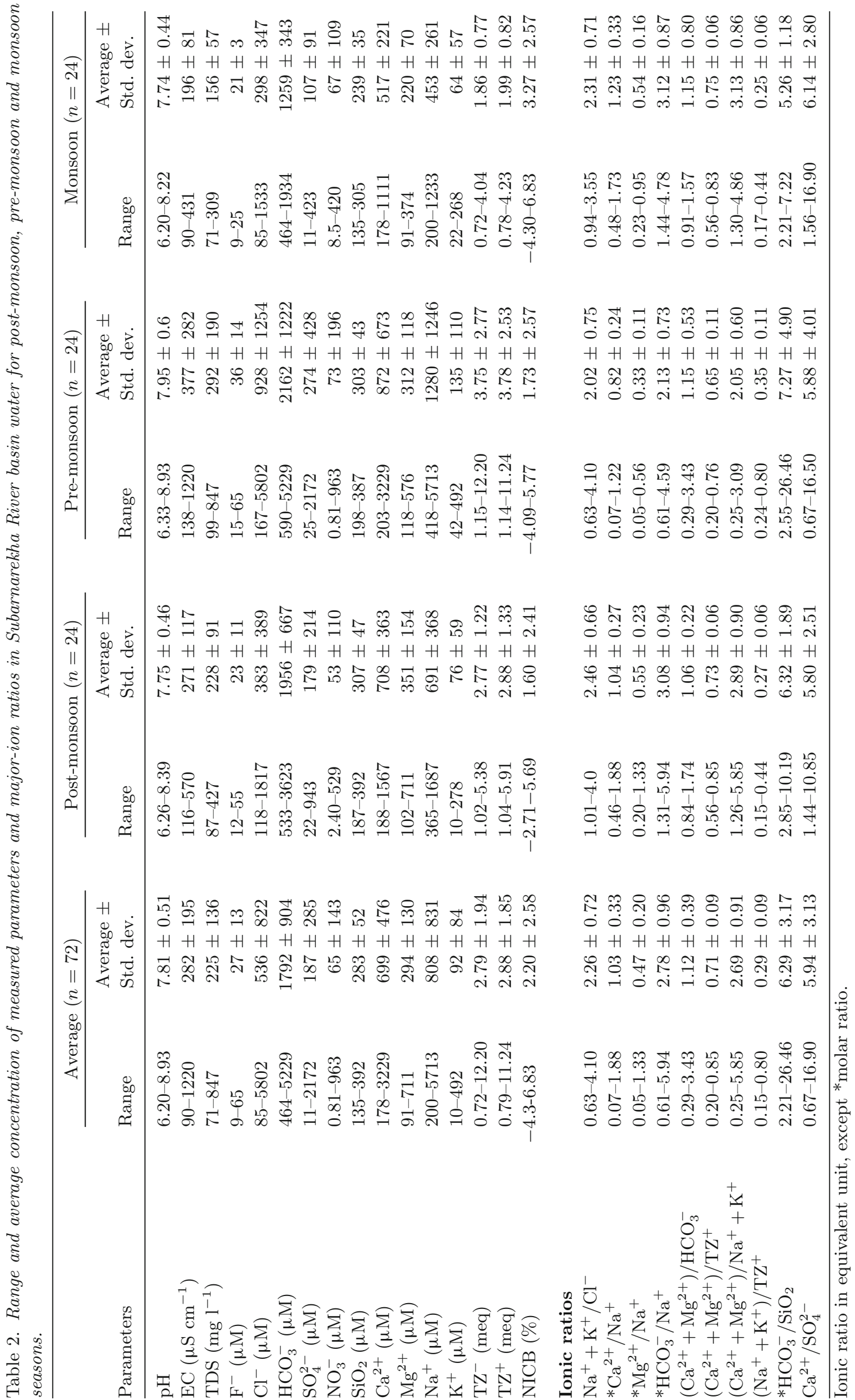


in the pre-monsoon $\left(292 \mathrm{mg} \mathrm{l}^{-1}\right)$ as compared to the post-monsoon $\left(228 \mathrm{mg} \mathrm{l}^{-1}\right)$ and monsoon $\left(156 \mathrm{mg} \mathrm{l}^{-1}\right)$ seasons. Seasonal variation of EC and TDS values indicates an increase in ionic concentrations during the pre-monsoon season, probably due to excessive evaporation and/or contribution from the groundwater in the summer months and dilution effects of atmospheric precipitation in the monsoon season. The elevated temperature in the hot summer months increases water evaporation and causes a reduction in river flow, resulting in an enhancement in solute concentration. Spatial variations in ionic concentration show a sharp increase at the Namkum-Tatisilwai-Muri industrial zone (sites 2, 3 and 5) and for the Garra tributary (T-4). Namkum, Tatisilwai and Muri are under the influence of industrial activities. Huge quantities of industrial and urban effluents are discharged into the Kharkai and the main Subarnarekha River at these locations. Tributary Garra receives highly polluted water and effluents with high sulphate contents and has high concentration of total suspended and dissolved solids mainly in the Jaduguda-Ghatsila mining complex areas.

$\mathrm{HCO}_{3}^{-}, \mathrm{Ca}^{2+}, \mathrm{Na}^{+}$and dissolved silica account for $>75 \%$ of the total dissolved loads and dominate the major-ion chemistry of the Subarnarekha River water. The $\mathrm{HCO}_{3}^{-}$was the most dominant anion in the surface water of the Subarnarekha River followed by $\mathrm{Cl}^{-}, \mathrm{SO}_{4}^{2-}, \mathrm{NO}_{3}^{-}$ and $\mathrm{F}^{-}$. The major anions constitute $65 \%$ of the TDS. The plot of the analytical data on anion diagram relating $\mathrm{HCO}_{3}^{-}, \mathrm{Cl}^{-}$and $\mathrm{SO}_{4}^{2-}$ shows the clustering of plotted points near the $\mathrm{HCO}_{3}^{-}$apex with a secondary trend towards $\mathrm{Cl}^{-}$ and $\mathrm{SO}_{4}^{-2}$ (figure 2a). Bicarbonate concentration ranged from 464 to $5229 \mu \mathrm{M}$ with an average value of $1792 \mu \mathrm{M}$ and it contributed $69 \%$ (20$87 \%)$ to the total anionic $\left(\mathrm{TZ}^{-}\right)$charge balance in equivalent unit. Bicarbonate in river water is mainly contributed from the dissolution of atmospheric $\mathrm{CO}_{2}$ and weathering of carbonates and/or silicate minerals by the carbonic acid. The $\mathrm{CO}_{2}$ in the subsurface environment is mainly originated from the decomposition of organic matter, which in turn combines with rainwater to form bicarbonates.

Chloride $\left(\mathrm{Cl}^{-}\right)$concentration in the analysed water samples of the Subarnarekha River ranged from 85 to $5802 \mu \mathrm{M}$ (avg. $536 \mu \mathrm{M}$ ) and it accounts for $16 \%$ of the total anionic charge $\left(\mathrm{TZ}^{-}\right)$. Except halite, most of the rock types contain very low
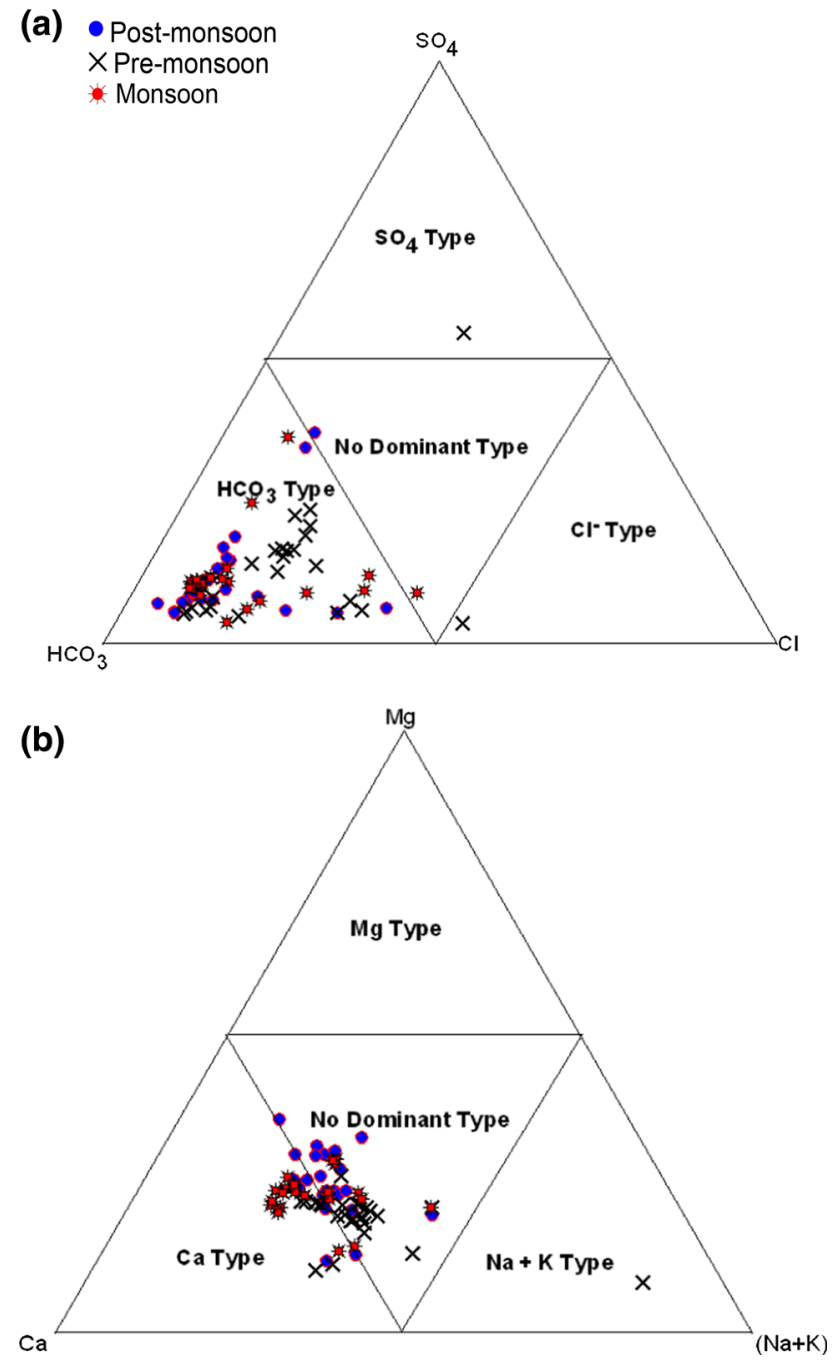

Figure 2. (a) Ternary anion diagram relating $\mathrm{HCO}_{3}, \mathrm{SO}_{4}$ and $\mathrm{Cl}$ and (b) ternary cation diagram relating $\mathrm{Ca}, \mathrm{Mg}$ and $(\mathrm{Na}+\mathrm{K})$.

concentration of chloride and it is believed that the major portion of $\mathrm{Cl}^{-}$in water is primarily derived from either the atmospheric source or the sea water (Berner and Berner 1987). Leaching of salt and saline residues in the soil, municipal, industrial, animal wastes and usage of fertiliser also plays a vital role as the source of chloride (Appelo and Postma 1996; Singh et al. 2008). Large spatial variations and increased chloride concentrations at sites $\mathrm{W}-2, \mathrm{~W}-3$ and $\mathrm{W}-23$ may be attributed to anthropogenic sources. The concentration of $\mathrm{SO}_{4}^{2-}$ and $\mathrm{NO}_{3}^{-}$in the surface water of the Subarnarekha River basin was found in the range of 11-2172 and $0.81-963 \mu \mathrm{M}$ and it accounted for $12 \%$ and $2.3 \%$ of the total anionic charge $\left(\mathrm{TZ}^{-}\right)$balance, respectively. Relatively the higher concentration of nitrate at Namkum (W-2) and Tatisilwai (W-3) sites indicates the anthropogenic contribution from 


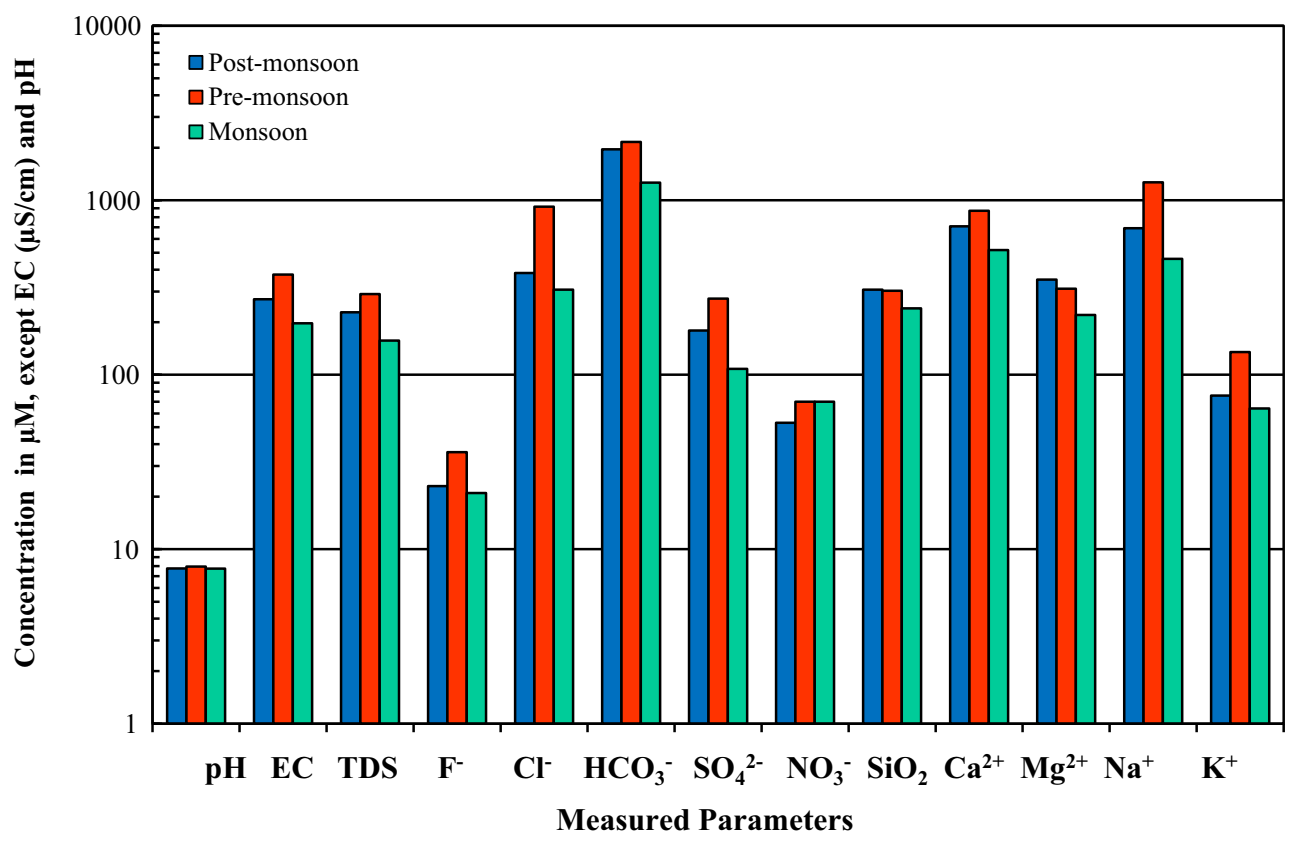

Figure 3. Average concentration of measured parameters in Subarnarekha basin water.

the leaching of fertiliser from agricultural fields. The concentration of $\mathrm{F}^{-}$varied from 9 to $65 \mu \mathrm{M}$ (avg. $27 \mu \mathrm{M}$ ) and on an average it contributed 1.2\% to the total anions $\left(\mathrm{TZ}^{-}\right)$.

$\mathrm{Ca}^{2+}, \mathrm{Mg}^{2+}, \mathrm{Na}^{+}$and $\mathrm{K}^{+}$together constitute $25 \%$ of the TDS. Calcium was the most dominant cation in the water of the Subarnarekha River, contributing $49 \%$ of the total cations $\left(\mathrm{TZ}^{+}\right)$ followed by $\mathrm{Na}^{+}(26 \%), \mathrm{Mg}^{2+}(22 \%)$ and $\mathrm{K}^{+}(3 \%)$. The calcium concentration ranged from 178 to $3229 \mu \mathrm{M}$, while the concentration of $\mathrm{Na}^{+}$varied from 200 to $5713 \mu \mathrm{M}$. The concentration of $\mathrm{Mg}^{2+}$ and $\mathrm{K}^{+}$ranged from 91 to 711 and 10 to $492 \mu \mathrm{M}$, respectively, with an average value of 294 and $92 \mu \mathrm{M}$. $\mathrm{Ca}^{2+}$ and $\mathrm{Mg}^{2+}$ together account for about $71 \%$ of the total cationic charge balance in the equivalent unit. The cation concentration in the Subarnarekha basin water generally followed the decreasing order of $\mathrm{Ca}^{2+}>\mathrm{Na}^{+}>\mathrm{Mg}^{2+}>\mathrm{K}^{+}$ with some minor exceptional samples, where $\mathrm{Na}^{+}$ concentration was found to be higher than the $\mathrm{Ca}^{2+}$ or $\mathrm{Mg}^{2+}$ exceeding the $\mathrm{Na}^{+}$concentration. The plot of the analytical data on cation diagram relating $\mathrm{Ca}^{2+}, \mathrm{Mg}^{2+}$ and $\left(\mathrm{Na}^{+}+\mathrm{K}^{+}\right)$shows that the plotted points of the water samples fall either in the 'calcium' or in 'no dominant' zone (figure $2 \mathrm{~b})$. Dissolved silica $\left(\mathrm{SiO}_{2}\right)$ concentration in the Subarnarekha River water varied from 187 to $392 \mu \mathrm{M}$ during the post-monsoon, 198 to $387 \mu \mathrm{M}$ in the pre-monsoon and 135 to $305 \mu \mathrm{M}$ in the monsoon (table 2). On average, the dissolved silica accounted for 9\% (2-19\%) of the TDS and it exceeds the chloride and sulphate concentrations at many sites. The average concentration of dissolved silica $(283 \mu \mathrm{M})$ in the studied river water is higher than the average global $(200 \mu \mathrm{M})$ and Indian $(117 \mu \mathrm{M})$ rivers (Ramanathan et al. 1994). The higher concentration of dissolved silica in the Subarnarekha River reflects the important contribution from the weathering of silicate rocks. The average $\mathrm{HCO}_{3} / \mathrm{SiO}_{2}$ molar ratio for the Subarnarekha and its tributaries vary between 2 and 26 (avg. 6.3); however, in a majority of samples it ranges between 5 and 10 , indicating the combined influence of carbonate and silicate weathering (Hounslow 1995). The high $\mathrm{HCO}_{3} / \mathrm{SiO}_{2}$ ratio $(>10)$ in some water samples can result from the supply of alkalinity from carbonates, salt affected soils and/or anthropogenic sources. No specific trend has been observed in the downstream variation of dissolved ionic concentrations. In general, the temporal variation of average concentration of major ions on the river basin scale follows a decreasing order of pre-monsoon $>$ postmonsoon $>$ monsoon (figure 3 ).

The trilinear Piper plot (Piper 1944) for the Subarnarekha River water reveals the dominance of alkaline earth $\left(\mathrm{Ca}^{2+}+\mathrm{Mg}^{2+}\right)$ metals over alkalis $\left(\mathrm{Na}^{+}+\mathrm{K}^{+}\right)$and weak acid $\left(\mathrm{HCO}_{3}^{-}\right)$over strong acids $\left(\mathrm{SO}_{4}^{2-}+\mathrm{Cl}^{-}\right)$. The plotted points of majority of samples fall in the field 5, signifying the carbonate hardness (secondary salinity) 


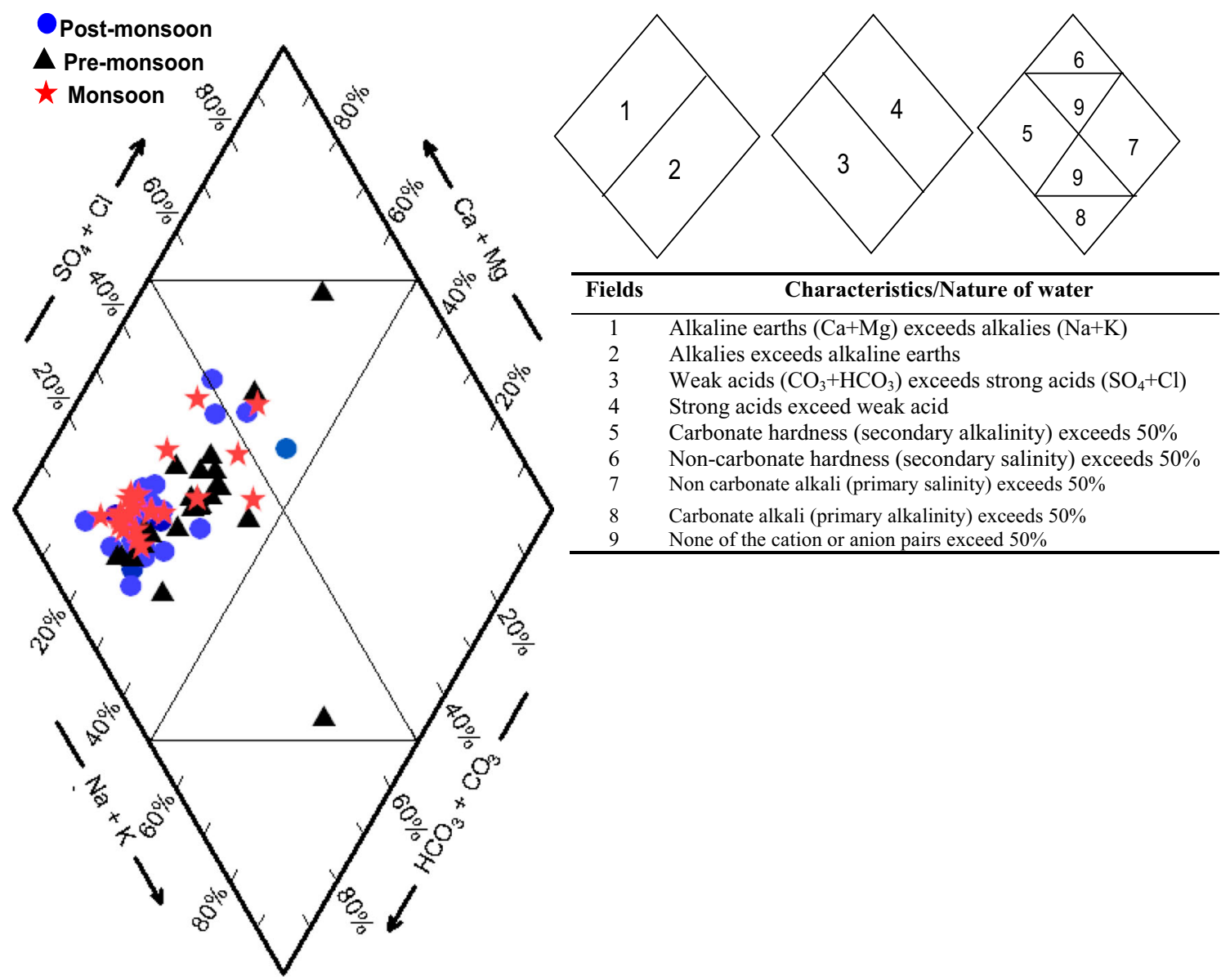

Figure 4. Piper trilinear diagram showing the hydrogeochemical character of river water and hydrochemical facies (after Piper 1953).

that exceeds $50 \%$ (figure 4). Only five water samples fall in the field 9, indicating water of an intermediate (mixed) chemical character having no one cation-anion pair exceeding $50 \%$. $\mathrm{Ca}-\mathrm{HCO}_{3}$ and $\mathrm{Ca}-\mathrm{Mg}-\mathrm{HCO}_{3}-\mathrm{Cl}$ are identified as the dominant hydrogeochemical facies in the surface water of the Subarnarekha River basin.

The average chemical composition of the Subarnarekha River basin water along with some other Indian Rivers and the world and Indian averages is summarised in table 3 . The TDS content of the Subarnarekha basin water is higher than that of the Indus, Brahmaputra, Godavari, Damodar and the Indian and world average rivers, but it is lower as compared to the Krishna, Cauvery, Narmada, Tapti, Mahi and Gomti rivers and comparable to Mahanadi, Son and Ganges averages. Like other Indian rivers, the Subarnarekha has high alkalinity, indicating the extent of mixing with $\mathrm{HCO}_{3}$-rich groundwater and atmospherically regulated $\mathrm{PCO}_{2}$-water reactions, which may further enhance the carbonate alkalinity. Potassium concentrations do not show much variation in the Subarnarekha water as in the other river basins, suggesting conservative behaviour of this element. Berner and Berner (1987) reported that only $15 \%$ of the river transport of potassium is in the dissolved form. The low concentration of dissolved $\mathrm{K}$ in water may be attributed to the resistance of potassium bearing minerals (orthoclase, microcline) against weathering. Potassium is commonly fixed in specific clay minerals, after being released during the primary weathering reactions and therefore does not behave in the same way as the other weathering derived ions (Stott and Burt 1997). The higher contributions of dissolved silica, $\mathrm{Na}^{+}$and $\mathrm{SO}_{4}^{2-}$ to the TDS in comparison to the other river basins may be attributed to silicate weathering and inputs from the sulphide weathering and anthropogenic sources in the drainage basin.

\subsection{Weathering and solute acquisition processes}

Chemical load in the river basin is considered to be a reflection of its watershed and floodplains and processes occurring in the tributaries 


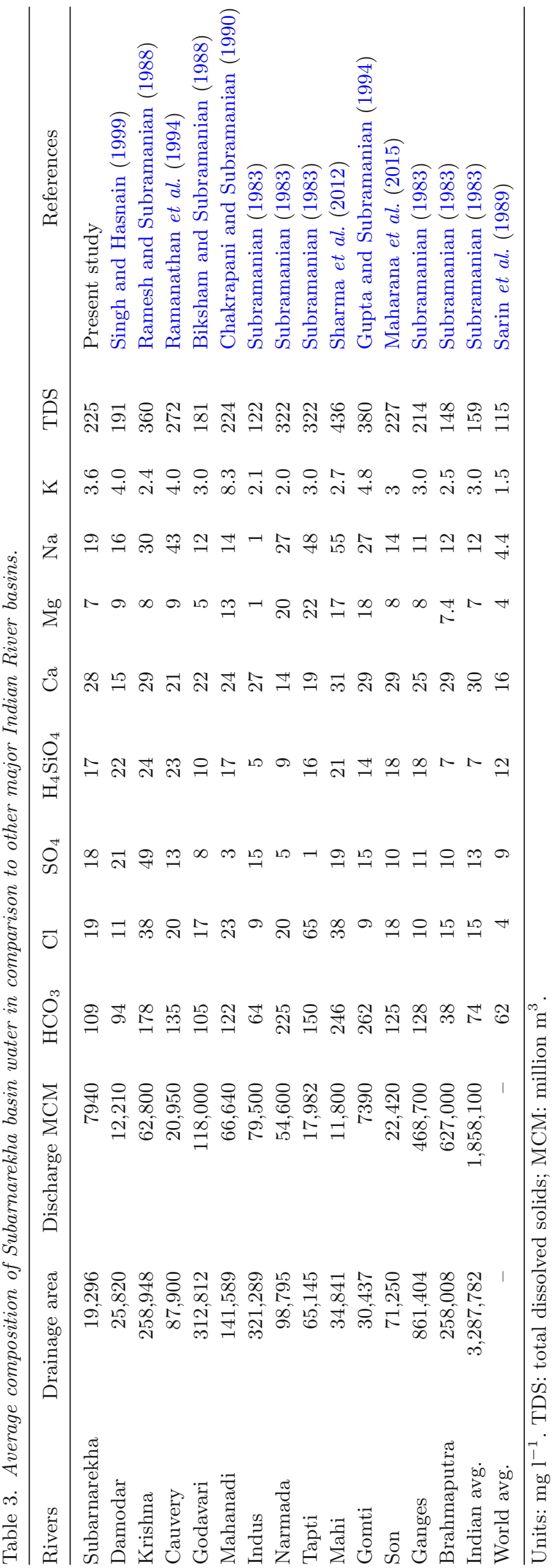

(Richey et al. 1990). Berner and Berner (1996) identified three possible sources of dissolved salt into the inland waters as (i) sea salt carried in the atmosphere and deposited on the land; (ii) weathering reaction taking place in the drainage basin and (iii) anthropogenic input. The proportions of contribution from these sources vary in space and time, resulting in seasonal and downstream variations in the chemical composition within the river basin. The atmospheric contribution to the dissolved salt in the inland water has been discussed by various authors (Stallard and Edmond 1983; Sarin et al. 1989; Berner and Berner 1996). The input of chloride concentration through precipitation is generally used as a parameter for evaluating the atmospheric contribution. This is because of the fact that $\mathrm{Cl}^{-}$is regarded as a conservative element as it reacts very little with other ions, does not form complexes and also does not participate in the biogeochemical cycling, except in small basins where biota plays a dominant role (Viers et al. 2001). The atmospheric contribution to the dissolved salts in the aquatic water can be assessed by comparing the chemical composition with the local rainwater chemistry or by taking the ratios of elements to $\mathrm{Cl}^{-}$(Sarin et al. 1989; Pandey et al. 1994; Singh et al. 2005). The average $\mathrm{Na}^{+} / \mathrm{Cl}^{-}(2.03)$ and $\mathrm{K}^{+} / \mathrm{Cl}^{-}(0.23)$ ratios in the surface water of the Subarnarekha River were found to be higher as compared to marine aerosols $\left(\mathrm{Na}^{+} / \mathrm{Cl}^{-}=0.85\right.$ and $\left.\mathrm{K}^{+} / \mathrm{Cl}^{-}=0.0176\right)$. This indicates a limited contribution from the atmospheric precipitation and suggests that high proportions of dissolved ions in this water are derived from the weathering of rock-forming minerals and anthropogenic sources. The plot of geochemical data on Gibbs's diagram (Gibbs 1970) that represents the ratio of $\left(\mathrm{Na}^{+}+\mathrm{K}^{+}\right) /\left(\mathrm{Na}^{+}+\right.$ $\left.\mathrm{K}^{+}+\mathrm{Ca}^{2+}\right)$ and $\mathrm{Cl}^{-} /\left(\mathrm{Cl}^{-}+\mathrm{HCO}_{3}^{-}\right)$as a function of TDS also indicates the dominance of weathering of rocks as a major controlling factor to determine the surface water chemistry of the Subarnarekha basin (figure 5).

Weathering of different parent rocks (e.g., carbonates, silicates and evaporites) yields different combinations of dissolved cations and anions in the water (Drever 1988; Berner and Berner 1996). For instance, calcium and magnesium in the river water are mainly derived from the weathering of carbonate and silicate minerals and evaporite dissolution. Silicate weathering along with evaporite dissolution and atmospheric precipitation are the major sources of sodium and potassium in the river water. 

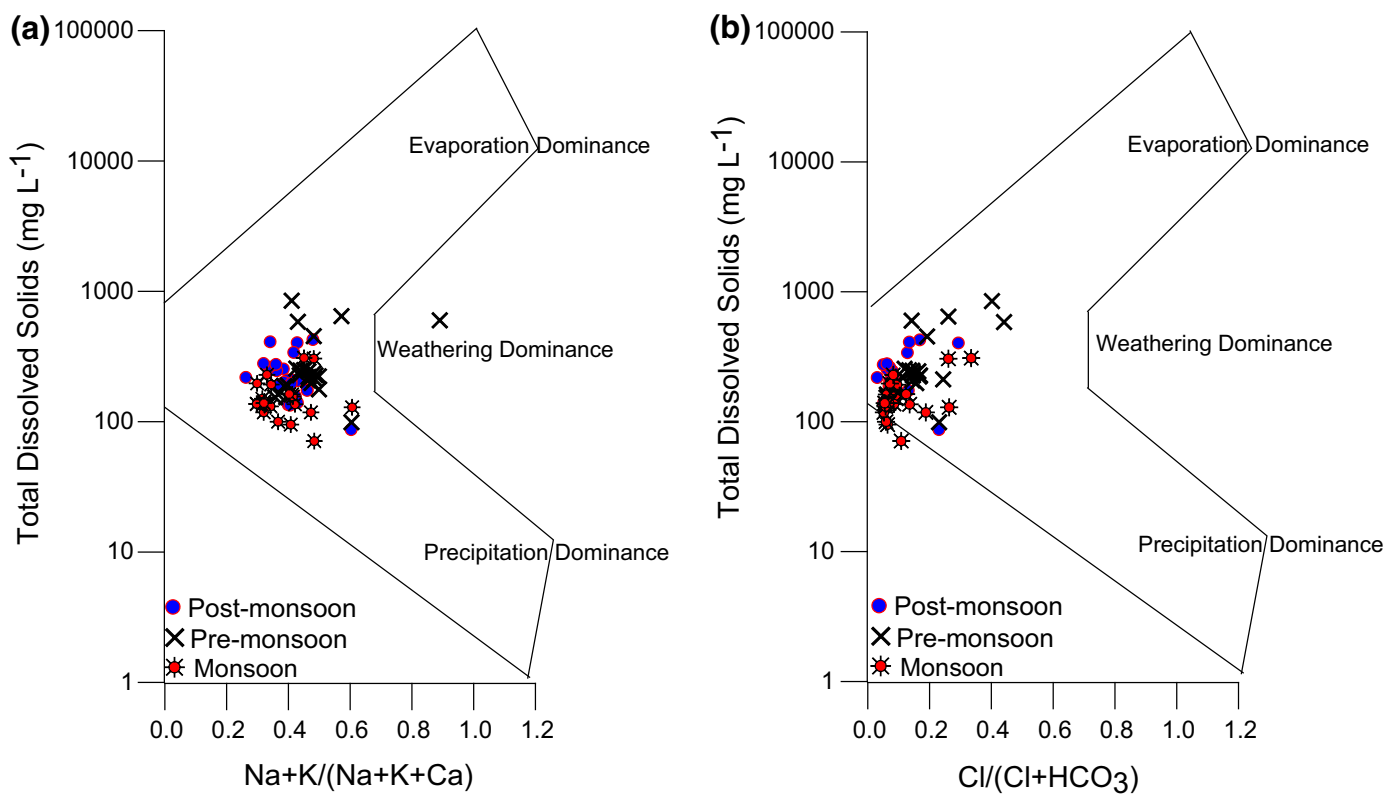

Figure 5. Gibbs's diagram representing the ratio of (a) $\mathrm{Na}+\mathrm{K} /(\mathrm{Na}+\mathrm{K}+\mathrm{Ca})$ and $(\mathbf{b}) \mathrm{Cl} /\left(\mathrm{Cl}+\mathrm{HCO}_{3}\right)$ as a function of $\mathrm{TDS}$ (after Gibbs 1970).

Dissolved silica is exclusively derived from the weathering of silicates. The plot of $\left(\mathrm{Ca}^{2+}+\mathrm{Mg}^{2+}\right)$ vs. $\left(\mathrm{HCO}_{3}^{-}+\mathrm{SO}_{4}^{2-}\right)$ will be close to $1: 1$ line if the dissolution of calcite, dolomite and gypsum is the dominant reaction in a system. Figure 6(a) shows that plotted points of the majority of the Subarnarekha water samples fall below the theoretical $1: 1$ trend line in the variation diagram relating $\left(\mathrm{Ca}^{2+}+\mathrm{Mg}^{2+}\right)$ to $\left(\mathrm{HCO}_{3}^{-}+\mathrm{SO}_{4}^{2-}\right)$. The excess of $\left(\mathrm{HCO}_{3}^{-}+\mathrm{SO}_{4}^{2-}\right)$ over $\left(\mathrm{Ca}^{2+}+\mathrm{Mg}^{2+}\right)$ suggests contribution from the non-carbonate source and demanding that the required portion of $\left(\mathrm{HCO}_{3}^{-}+\mathrm{SO}_{4}^{2-}\right)$ to be balanced by the alkalis $\left(\mathrm{Na}^{+}+\mathrm{K}^{+}\right)$. $\left(\mathrm{Ca}^{2+}+\mathrm{Mg}^{2+}\right) / \mathrm{HCO}_{3}^{-}$ratio demarcates the maximum portion of bicarbonate that can be derived from the carbonate weathering (Stallard and Edmond 1983). The variation diagram between $\left(\mathrm{Ca}^{2+}+\mathrm{Mg}^{2+}\right)$ and $\mathrm{HCO}_{3}^{-}$for the Subarnarekha basin water shows that in the majority of samples $\left(\mathrm{Ca}^{2+}+\mathrm{Mg}^{2+}\right)$ the contents are in excess of alkalinity and the magnitude of excess being larger for the tributaries (figure 6b). The excess of $\left(\mathrm{Ca}^{2+}+\mathrm{Mg}^{2+}\right)$ over bicarbonate in these waters indicates some extra source of $\mathrm{Ca}^{2+}$ and $\mathrm{Mg}^{2+}$ and excess part of the positive charges is balanced by other anions such as $\mathrm{SO}_{4}^{2-}$ and/or $\mathrm{Cl}^{-}$. The data plot along the equiline on $\left(\mathrm{Ca}^{2+}+\mathrm{Mg}^{2+}\right)$ vs. $\mathrm{TZ}^{+}$at lower concentration range suggests a significant contribution of $\mathrm{Ca}^{2+}$ and $\mathrm{Mg}^{2+}$ to the total cations. Deviations of plotted points from 1:1 equiline at higher concentration especially during the pre-monsoon indicate the increasing contribution of alkalis $\left(\mathrm{Na}^{+}+\mathrm{K}^{+}\right)$ to the total cations with increasing ionic concentrations (figure 6c).

The concentrations of $\left(\mathrm{Na}^{+}+\mathrm{K}^{+}\right)$in the analysed water samples are significantly in excess over chloride and high $\left(\mathrm{Na}^{+}+\mathrm{K}^{+}\right) / \mathrm{Cl}^{-}$ratio i.e., 2.26 suggests non-atmospheric source of alkalis which might be derived from silicates weathering (figure $6 \mathrm{~d}) .\left(\mathrm{Na}^{+}+\mathrm{K}^{+}\right) / \mathrm{TZ}^{+}$and $\left(\mathrm{Ca}^{2+}+\mathrm{Mg}^{2+}\right) /$ $\left(\mathrm{Na}^{+}+\mathrm{K}^{+}\right)$ratios can be used as an index to assess the contribution of cations through silicate weathering (Stallard and Edmond 1983; Sarin et al. 1989). The plot of $\left(\mathrm{Na}^{+}+\mathrm{K}^{+}\right)$vs. $\mathrm{TZ}^{+}$shows the deviation of plotted points from the 1:1 equiline and the $\left(\mathrm{Na}^{+}+\mathrm{K}^{+}\right) / \mathrm{TZ}^{+}$ratio varies between 0.15 and 0.80 (figure 6e). The $\left(\mathrm{Ca}^{2+}+\mathrm{Mg}^{2+}\right) /$ $\left(\mathrm{Na}^{+}+\mathrm{K}^{+}\right)$molar abundance ratio in the silicates of upper crust is generally 1.0 (Taylor and McLennan 1985). The average $\left(\mathrm{Ca}^{2+}+\mathrm{Mg}^{2+}\right) /\left(\mathrm{Na}^{+}+\mathrm{K}^{+}\right)$ ratio in the Subarnarekha River water is 2.7 , comparable to the world (2.2) and Indian (2.5) river water averages (figure 6f). The observed low $\left(\mathrm{Ca}^{2+}+\mathrm{Mg}^{2+}\right) /\left(\mathrm{Na}^{+}+\mathrm{K}^{+}\right)$ratio, i.e., 2.7 and higher $\left(\mathrm{Na}^{+}+\mathrm{K}^{+}\right) / \mathrm{TZ}^{+}$, i.e., 0.29 ratio in the analysed waters suggest that the chemical composition of the Subarnarekha River is under the combined influence of carbonate and silicate weathering (Sarin et al. 1989; Singh et al. 2005).

Small rivers draining only carbonates are characterised by higher calcium and magnesium concentrations and have high $\mathrm{Ca}^{2+} / \mathrm{Na}^{+}$, i.e., 50; 

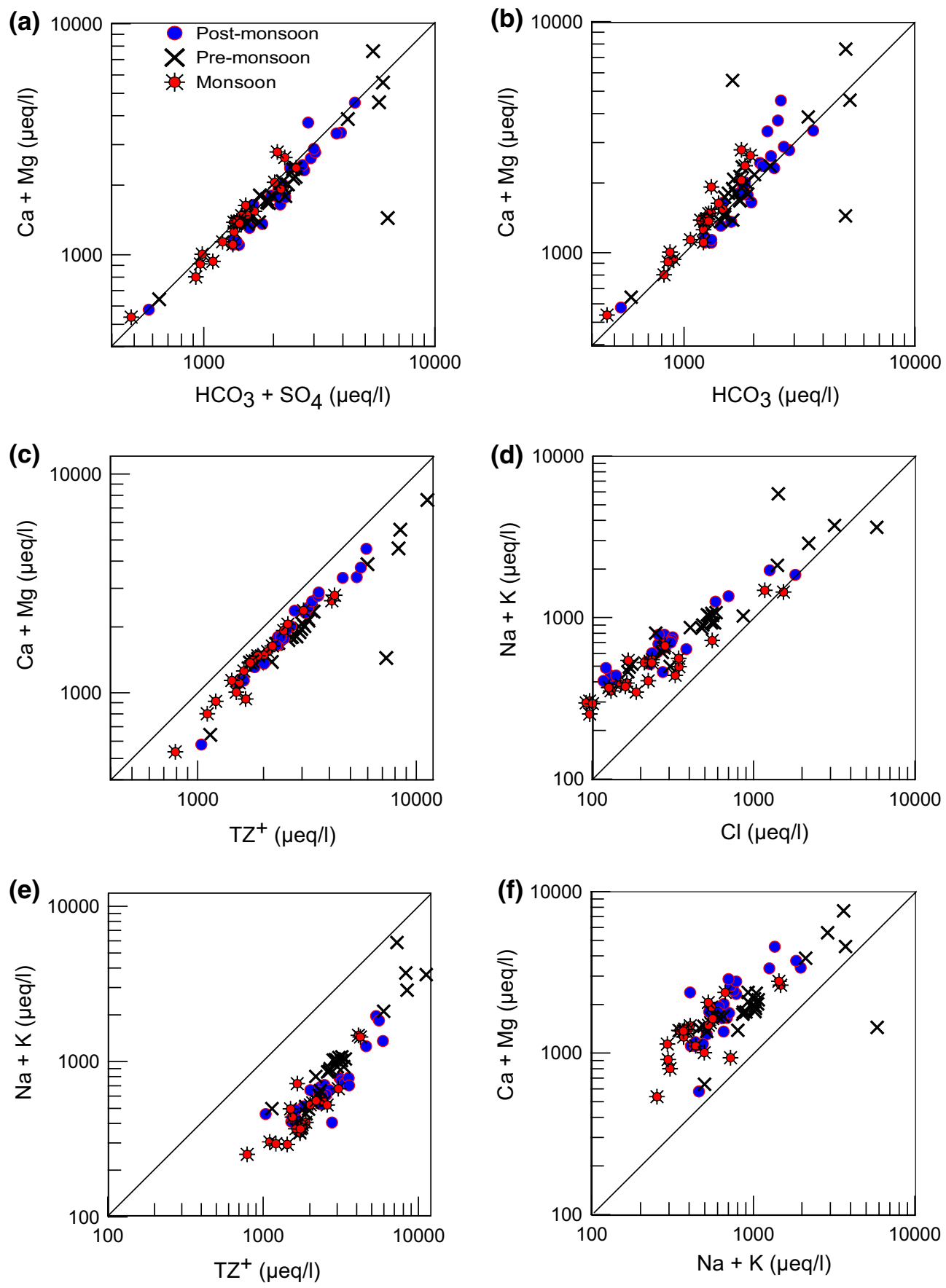

Figure 6. Scatter plot between (a) $\mathrm{Ca}+\mathrm{Mg}$ vs. $\mathrm{HCO}_{3}+\mathrm{SO}_{4}$, (b) $\mathrm{Ca}+\mathrm{Mg}$ vs. $\mathrm{HCO}_{3}$, (c) $\mathrm{Ca}+\mathrm{Mg}$ vs. total cations, (d) $\mathrm{Na}+\mathrm{K}$ vs. $\mathrm{Cl},(\mathbf{e}) \mathrm{Na}+\mathrm{K}$ vs. total cations and (f) $\mathrm{Ca}+\mathrm{Mg}$ vs. $\mathrm{Na}+\mathrm{K}$.

$\mathrm{Mg}^{2+} / \mathrm{Na}^{+}$, i.e., 10 ; and $\mathrm{HCO}_{3}^{-} / \mathrm{Na}^{+}$, i.e., 120 ratios (Gaillardet et al. 1999). The dissolved loads of water draining silicate terrains is expected to have a low $\mathrm{Ca}^{2+} / \mathrm{Na}^{+}$molar ratio because of higher solubility of $\mathrm{Na}^{+}$relative to $\mathrm{Ca}^{2+}$. The molar ratios of $\mathrm{Ca}^{2+} / \mathrm{Na}^{+}=0.35 \pm 0.15, \mathrm{Mg}^{2+} / \mathrm{Na}^{+}=$ $0.24 \pm 0.12, \mathrm{HCO}_{3}^{-} / \mathrm{Na}^{+}=2 \pm 1$ are assigned for the silicate end member. The observed molar ratios of $\mathrm{Ca}^{2+} / \mathrm{Na}^{+}$(1.04), $\mathrm{Mg}^{2+} / \mathrm{Na}^{+}(0.48)$ and
$\mathrm{HCO}_{3}^{-} / \mathrm{Na}^{+}$(2.78) in the Subarnarekha River waters are much lower than those of the waters draining carbonate lithology and higher than that drain silicate rocks, indicating that the solute chemistry of the Subarnarekha River is essentially controlled by two-component mixing from the dissolution of silicates and carbonates. The plots of $\mathrm{HCO}_{3}^{-} / \mathrm{Na}^{+}$vs. $\mathrm{Ca}^{2+} / \mathrm{Na}^{+}$and $\mathrm{Ca}^{2+} / \mathrm{Na}^{+}$ vs. $\mathrm{Mg}^{2+} / \mathrm{Na}^{+}$relating carbonate and silicate end 

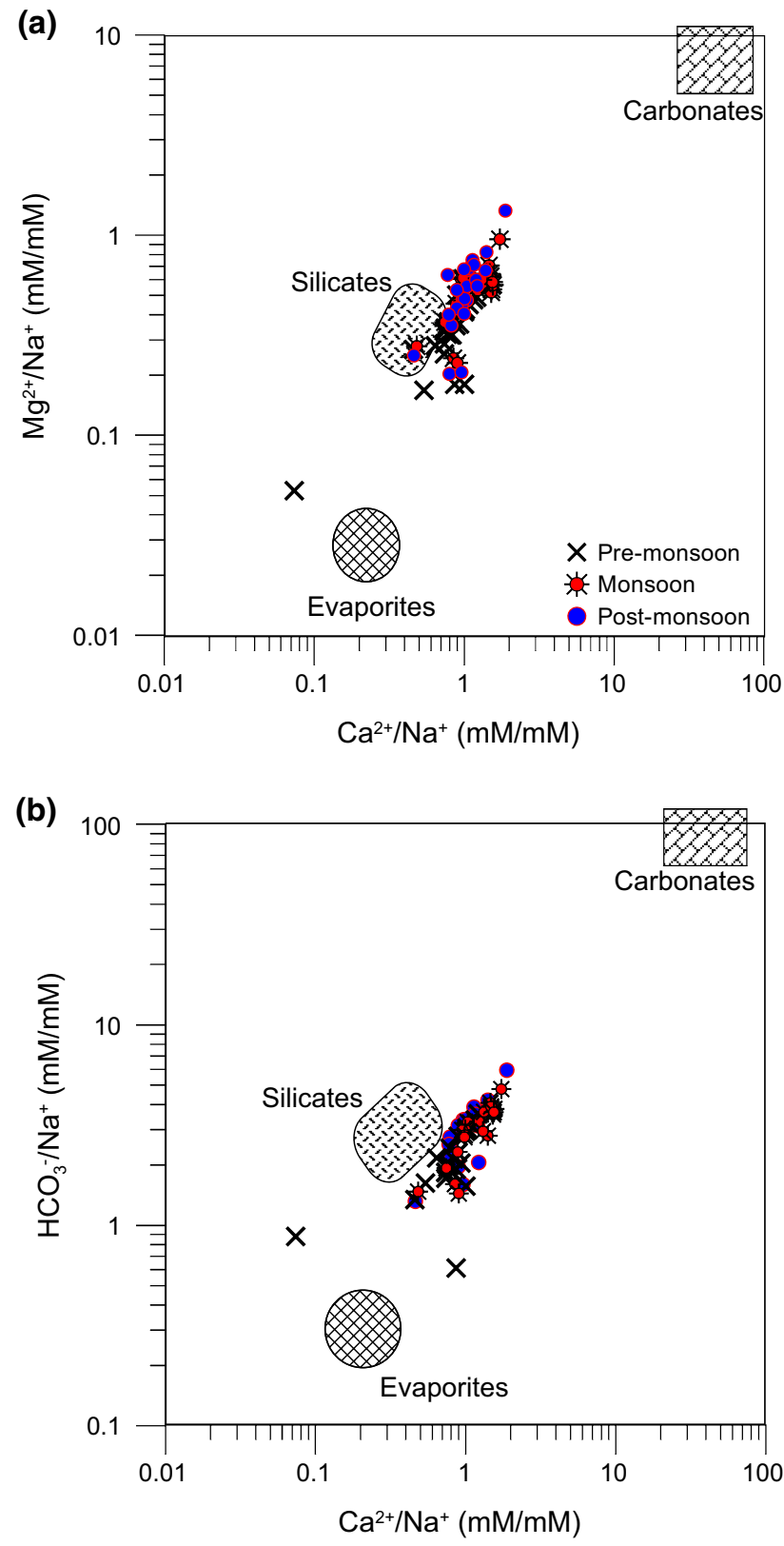

Figure 7. Mixing diagrams using sodium normalised ratio of (a) $\mathrm{Mg}^{2+} / \mathrm{Na}^{+}$vs. $\mathrm{Ca}^{2+} / \mathrm{Na}^{+}$and (b) $\mathrm{HCO}_{3}^{-} / \mathrm{Na}^{+}$vs. $\mathrm{Ca}^{2+} / \mathrm{Na}^{+}$relating carbonate and silicate end members (after Gaillardet et al. 1999).

members show the dominance of silicate weathering over the carbonate dissolution in solute acquisition processes in the Subarnarekha River basin (figure 7 ).

\subsection{Saturation index and water mineral equilibrium}

The saturation index (SI) of the studied water with respect to calcite $\left(\mathrm{SI}_{c}\right)$ and dolomite $\left(\mathrm{SI}_{d}\right)$ was estimated using the USGS hydrogeochemical software PHREEQC (Parkhurst and Appelo 1999) in order to investigate the level to which the natural water has equilibrated with the carbonate mineral phases. PHREEQC is a widely used modelling code that employs various approaches and thermodynamic databases for solving solutionsolid-gas equilibria (Lecomte et al. 2005; Binet et al. 2009; Tiwari and Singh 2014). The saturation index of a particular mineral phase can be defined as $\mathrm{SI}=\log _{10}\left(\mathrm{IAP} / K_{s p}\right)$, where IAP is the ion activity product of the solution and $K_{s p}$ is the solubility product at a given temperature (Garrels and Mackenzie 1967). A positive saturation index specifies that the water is being supersaturated with respect to a particular mineral phase and therefore incapable of dissolving more of the mineral and the mineral phase in equilibrium precipitate under suitable physico-chemical condition. Undersaturation condition is denoted by a negative index and suggests the dissolution of mineral phase, while neutral SI denotes the equilibrium state with the mineral phase. The plot of saturation index of calcite $\left(\mathrm{SI}_{c}\right)$ vs. dolomite $\left(\mathrm{SI}_{d}\right)$ demonstrates that most of the post-monsoon and monsoon water samples are undersaturated with respect to dolomite and calcite, while water is supersaturated with respect to both during the premonsoon (figure 8). The supersaturation condition in pre-monsoon may be attributed to evaporation effects during the lean water level period of summer season which causes the preferential extraction of Ca by precipitation (Hardie and Eugster 1970). The undersaturation condition represents water that has come from an environment where rock matrices contain insufficient calcite and dolomite or where $\mathrm{Ca}$ and $\mathrm{Mg}$ exist in other forms. Undersaturated waters are capable to dissolve calcite and/or dolomite when it comes in contact with source rocks.

The clay mineral assemblages, which would be consistent with the natural water chemistry, can be established through thermodynamic data (Garrels and Christ 1965). The thermodynamic stability relationships of the Subarnarekha River water are plotted in the silicate systems: (a) $\mathrm{Na}_{2} \mathrm{O}-\mathrm{Al}_{2}-\mathrm{SiO}_{2}-\mathrm{H}_{2} \mathrm{O}$, (b) $\mathrm{K}_{2} \mathrm{O}-\mathrm{Al}_{2}-\mathrm{SiO}_{2}-$ $\mathrm{H}_{2} \mathrm{O}$, (c) $\mathrm{CaO}-\mathrm{Al}_{2}-\mathrm{SiO}_{2}-\mathrm{H}_{2} \mathrm{O}$ and (d) $\mathrm{MgO}-$ $\mathrm{Al}_{2}-\mathrm{SiO}_{2}-\mathrm{H}_{2} \mathrm{O}$ at $25^{\circ} \mathrm{C}$ to predict the possible clay mineral assemblages which would be in equilibrium with the river water chemistry (figure 9). The $\mathrm{pH}-\log \mathrm{H}_{4} \mathrm{SiO}_{4}$ stability diagram demonstrates that the majority of data points fall in the range of kaolinite stability field except some 


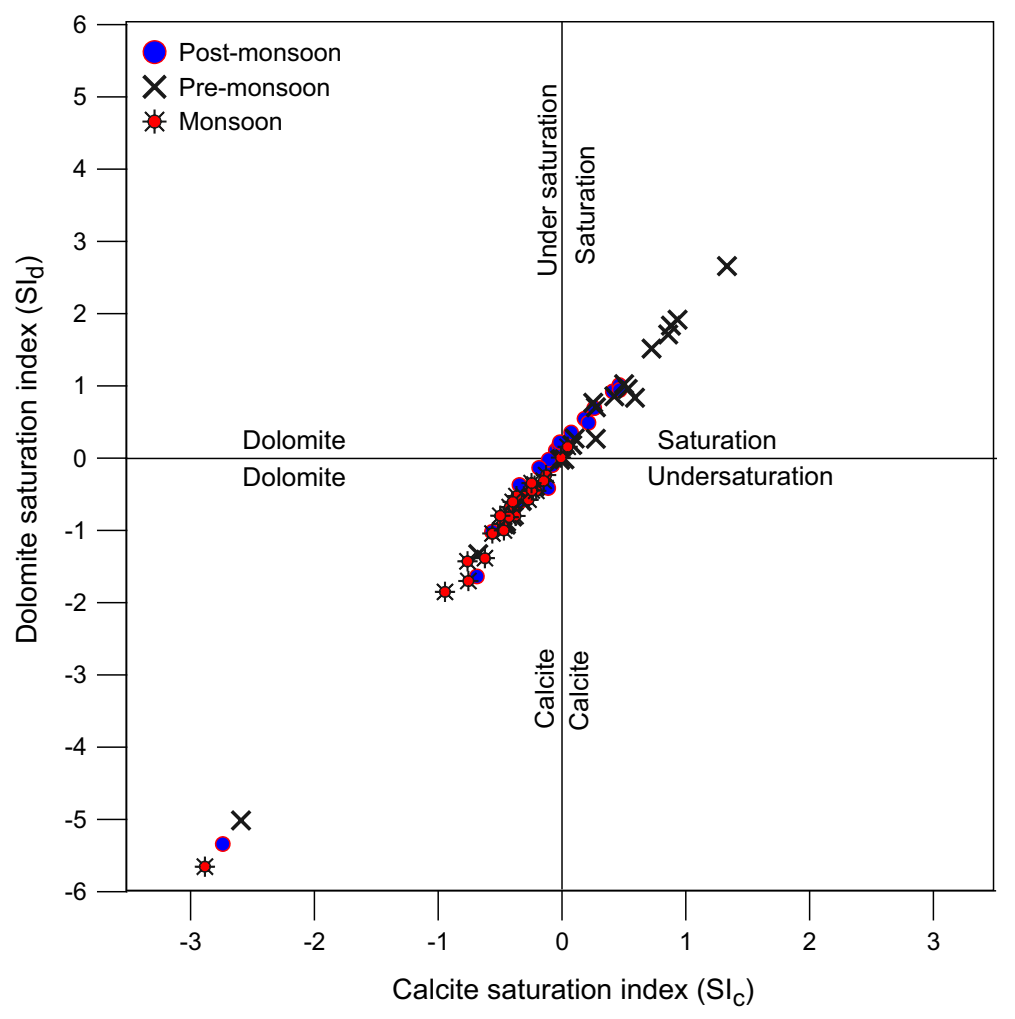

Figure 8. Relationship between saturation indices of calcite $\left(\mathrm{SI}_{c}\right)$ and dolomite $\left(\mathrm{SI}_{d}\right)$.

pre-monsoon samples which fall in the chlorite and Ca-feldspar zones in $\mathrm{MgO}-\mathrm{Al}_{2}-\mathrm{SiO}_{2}-\mathrm{H}_{2} \mathrm{O}$ and in $\mathrm{CaO}-\mathrm{Al}_{2}-\mathrm{SiO}_{2}-\mathrm{H}_{2} \mathrm{O}$ system. The enrichment of $\mathrm{Mg}$ and $\mathrm{Ca}$ in the water during pre-monsoon may explain it (Das and Dhiman 2003). Watermineral equilibria imply that the Subarnarekha River water chemistry is in equilibrium with the kaolinite. Stability in the kaolinite field suggests that the $\mathrm{CO}_{2}$-enriched water reacts with silicate minerals contained in the host rock, particularly in plagioclase feldspar and converted into allophonehallosite-kaolinite. The reactive water leached out $\mathrm{Ca}, \mathrm{Mg}, \mathrm{Na}$ and $\mathrm{HCO}_{3}$ from the host silicates and results in a more silica-rich clay minerals by the reaction:

$$
\begin{aligned}
(\mathrm{Na}, \mathrm{K}, \mathrm{Ca}, \mathrm{Mg}) \text { silicates }+\mathrm{H}_{2} \mathrm{O}+\mathrm{CO}_{2} \\
=\mathrm{H}_{4} \mathrm{SiO}_{4}+\mathrm{HCO}_{3}+\mathrm{Na}+\mathrm{K} \\
\quad+\mathrm{Ca}+\mathrm{Mg}+\mathrm{Al}_{2} \mathrm{Si}_{2} \mathrm{O}_{5}(\mathrm{OH})_{4} \text { Clay mineral. }
\end{aligned}
$$

\subsection{Dissolved fluxes and chemical denudation rate}

The Subarnarekha River shows enormous spatial and temporal variations in the water discharge. Figure 10 shows the variation in water discharge for the monsoon and non-monsoon seasons at five locations. About $69-98 \%$ of the annual water discharge from the river occurs during the monsoon (June-September) and $2-31 \%$ in the lean flow period of non-monsoon (October-May). The annual dissolved fluxes and chemical denudation rates of the Subarnarekha River at various locations and its major tributaries were calculated by using the average TDS, catchment area and annual water discharge (table 4). The Subarnarekha River annually transported $0.179 \times 10^{6}$ ton of dissolved chemical loads to the Muri site and the estimated chemical denudation rate of the catchment at this site was 135 ton $\mathrm{km}^{-2} \mathrm{yr}^{-1}$. The dissolved load and water discharge increase unsystematically at downstream sites and the annual solute fluxes at Ghatsila and Rajghat sites were estimated to be in the range of $1.585 \times 10^{6}-1.477 \times$ $10^{6}$ ton, respectively. Kharkai, the largest Subarnarekha tributary, annually delivered $1.023 \times 10^{6}$ ton of dissolved loads to the Subarnarekha River at Adityapur. The annual solute fluxes of the other tributaries such as Sankh $\left(0.016 \times 10^{6}\right.$ ton $)$, Garra $\left(0.082 \times 10^{6}\right.$ ton $)$, Kanchi $\left(0.109 \times 10^{3}\right.$ ton $)$ and Karkari $\left(0.188 \times 10^{3}\right.$ ton $)$ were low as compared to the Kharkai $\left(1.023 \times 10^{6}\right.$ ton $)$. The chemical 
(a) 9

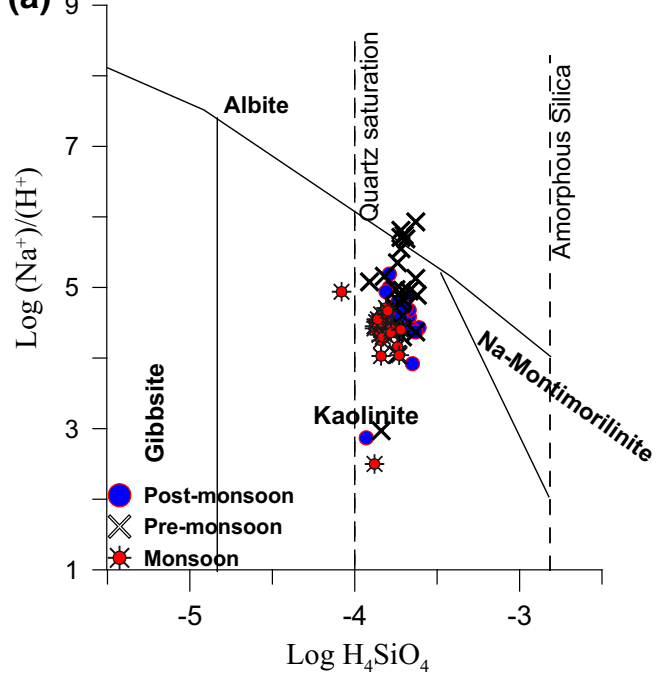

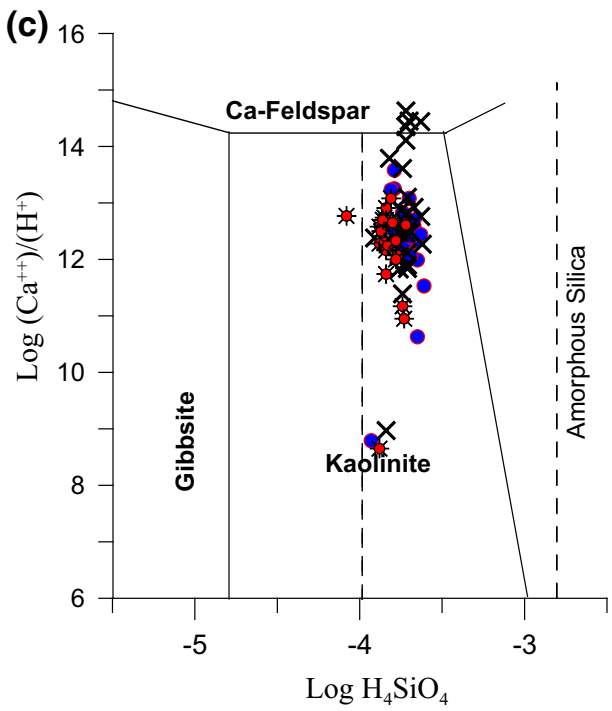

(d)

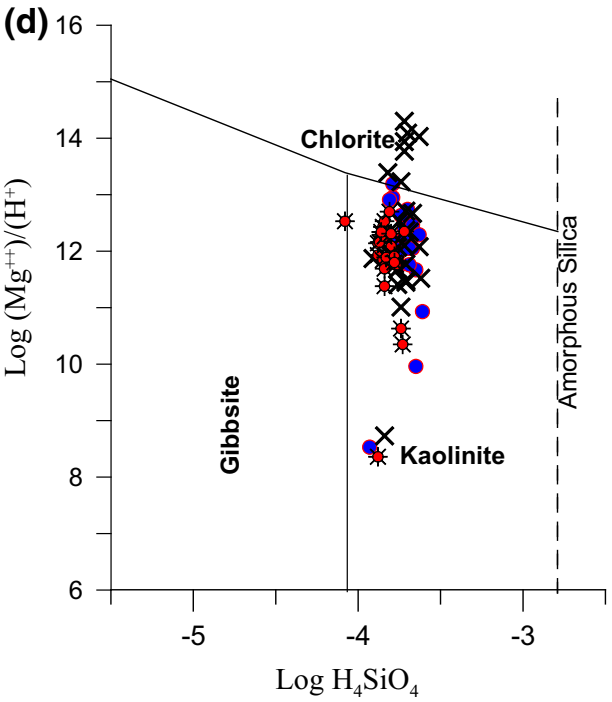

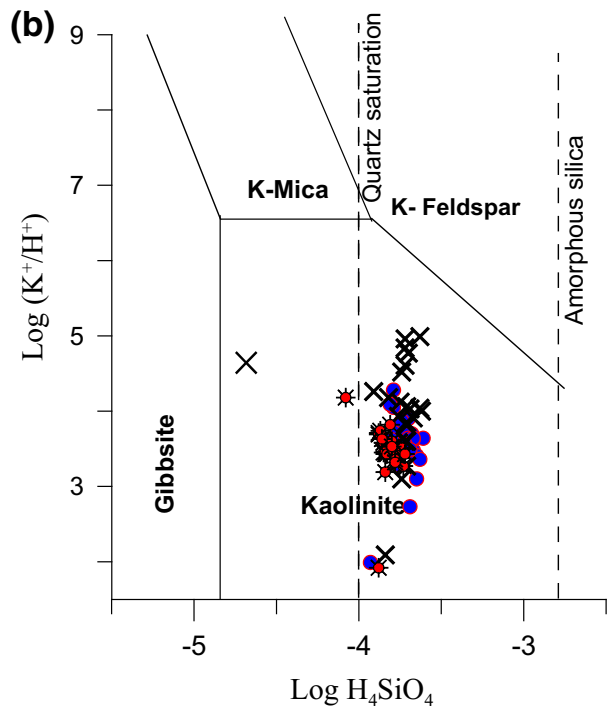

(a) $\mathrm{Na}_{2} \mathrm{O}-\mathrm{Al}_{2}-\mathrm{SiO}_{2}-\mathrm{H}_{2} \mathrm{O}$; (b) $\mathrm{K}_{2} \mathrm{O}-\mathrm{Al}_{2}-\mathrm{SiO}_{2}-\mathrm{H}_{2} \mathrm{O}$;

Figure 9. Mineral stability diagrams for the silicate system: (a) $\mathrm{Na}_{2} \mathrm{O}-\mathrm{Al}_{2}-\mathrm{SiO}_{2}-$
(c) $\mathrm{CaO}-\mathrm{Al}_{2}-\mathrm{SiO}_{2}-\mathrm{H}_{2} \mathrm{O}$; (d) $\mathrm{MgO}-\mathrm{Al}_{2}-\mathrm{SiO}_{2}-\mathrm{H}_{2} \mathrm{O}$ (after Garrels and Christ 1965).

denudation rates of the Kharkai, Garra, Karkari and Kanchi catchments were estimated to be in the range of 176, 169, 119 and 105 ton $\mathrm{km}^{-2} \mathrm{yr}^{-1}$, respectively.

\subsection{Water quality assessment for irrigation uses}

$\mathrm{EC}$ and $\mathrm{Na}$ are the most important parameters for determining the suitability of water for irrigation uses. High salt concentrations in the irrigation water affect the soil structure, permeability and aeration, which indirectly affect the plant growth. Irrigation water can be classified into low $\left(\mathrm{EC}=<250 \mu \mathrm{S} \mathrm{cm} \mathrm{c}^{-1}\right)$, medium $\left(250-750 \mu \mathrm{S} \mathrm{cm}^{-1}\right)$, high $\left(750-2250 \mu \mathrm{S} \mathrm{cm}^{-1}\right)$ and

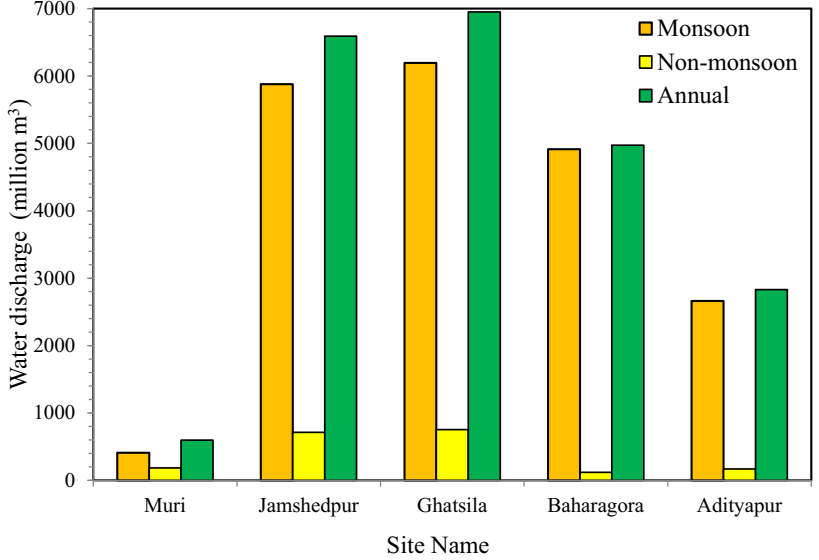

Figure 10. Seasonal variations in water discharge of the Subarnarekha and Kharkai rivers at different sites. 
Table 4. Average annual solute fluxes and chemical denudation rate of the Subarnarekha and its tributaries.

\begin{tabular}{|c|c|c|c|c|c|c|}
\hline$\underline{\text { River/tributary }}$ & $\begin{array}{c}\text { Site/tributaries } \\
\text { name }\end{array}$ & $\begin{array}{l}\text { Area } \\
\left(\mathrm{km}^{2}\right)\end{array}$ & $\begin{array}{l}\text { Discharge } \\
\left(\text { million } \mathrm{m}^{3}\right)\end{array}$ & $\begin{array}{c}\text { TDS } \\
\left(\mathrm{mg} \mathrm{l}^{-1}\right)\end{array}$ & $\begin{array}{c}\text { Solute flux } \\
\left(\times 10^{6}\right)\left(\text { ton } \mathrm{yr}^{-1}\right) \\
\end{array}$ & $\begin{array}{l}\text { Chemical } \\
\text { denudation rate } \\
\left(\text { ton } \mathrm{km}^{-2} \mathrm{yr}^{-1}\right)\end{array}$ \\
\hline \multirow[t]{6}{*}{ Subarnarekha } & Muri & 1330 & 596 & 301 & 0.179 & 135 \\
\hline & Adityapur & 6309 & 2831 & 310 & 0.878 & 139 \\
\hline & Jamshedpur & 12,649 & 6593 & 201 & 1.325 & 105 \\
\hline & Ghatsila & 14,176 & 6950 & 228 & 1.585 & 112 \\
\hline & Baharagora & - & 4974 & 190 & 0.945 & - \\
\hline & Rajghat & 19,296 & 7940 & 186 & 1.477 & 77 \\
\hline \multirow[t]{5}{*}{ Tributaries } & Kanchi & 1036 & 750 & 145 & 0.109 & 105 \\
\hline & Karkari & 1575 & 950 & 198 & 0.188 & 119 \\
\hline & Kharkai & 5825 & 3300 & 310 & 1.023 & 176 \\
\hline & Garra & 483 & 200 & 408 & 0.082 & 169 \\
\hline & Sankh & 196 & 80 & 202 & 0.016 & 82 \\
\hline
\end{tabular}

very high $\left(2250-5000 \mu \mathrm{S} \mathrm{cm}{ }^{-1}\right)$ salinity classes based on the total concentration of soluble salts in water (USSL 1954). The excess sodium in water produces undesirable effects on soil properties and reduces its permeability. High salt concentration in water results in the formation of saline soil, whereas a high sodium concentration leads to the development of alkaline soil. The alkali hazard in the use of water for irrigation is expressed in terms of sodium absorption ratio (SAR) and determined by the absolute and relative concentration of cations. On the basis of SAR value, water can be classified as low $(\mathrm{SAR}<6)$, medium (6-12), high (12-18) and very high $(>18)$ alkali water.

The calculated value of SAR in the surface water of the Subarnarekha River basin ranges from 0.32 to 6.73 (avg. 0.79). The plotted data of the majority of water samples on the US salinity diagram fall in the category of $\mathrm{C} 1 \mathrm{~S} 1$ and $\mathrm{C} 2 \mathrm{~S} 1$, i.e., low-tomedium salinity and low alkali water (figure 11). Such water can be used for irrigation in most of the soil and crops with little danger of development of exchangeable sodium and salinity. Four water samples of the pre-monsoon season fall in the zones of C3S1 and C3S2 indicating high salinity and low-to-medium alkali hazard. High saline waters are not suitable to irrigate the agricultural fields with restricted drainage and it requires special management for salinity control. For utilisation of such water, soil must be permeable, drainage must be adequate and irrigation water must be applied in excess to provide considerable leaching.

$\% \mathrm{Na}$ in water is a parameter computed to evaluate the suitability of water for irrigation use. $\% \mathrm{Na}$ denotes the relative proportions of alkali

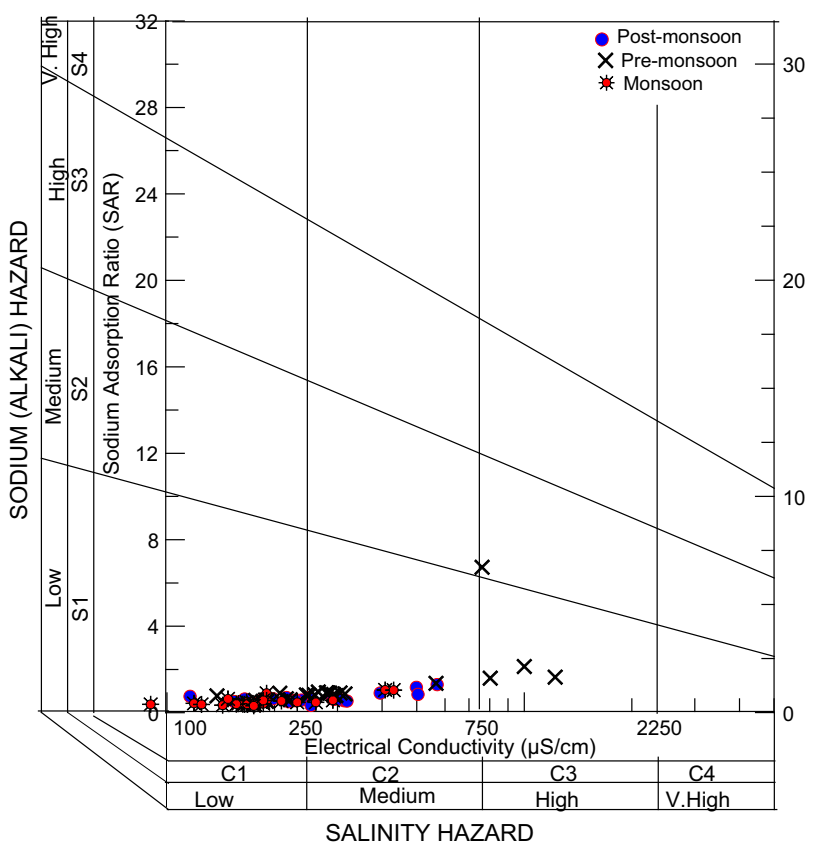

Figure 11. US salinity diagram for classification of irrigation waters (USSL 1954).

to the total cations. The role of sodium in the classification of irrigation water was emphasised because of the fact that sodium reacts with soil and affects its physical condition and soil structure including the formation of crusts and reduction in soil aeration, infiltration rate and soil permeability. Maximum $\% \mathrm{Na}$ of $60 \%$ is recommended for irrigation water. $\% \mathrm{Na}$ in the analysed river water ranges between 15 and $44 \%$ in the post-monsoon, 24 and $80 \%$ in the pre-monsoon and 17 and $44 \%$ in the monsoon seasons. The plot of analytical data on Wilcox (1955) diagram relating EC and $\% \mathrm{Na}$ placed the Subarnarekha River water under 


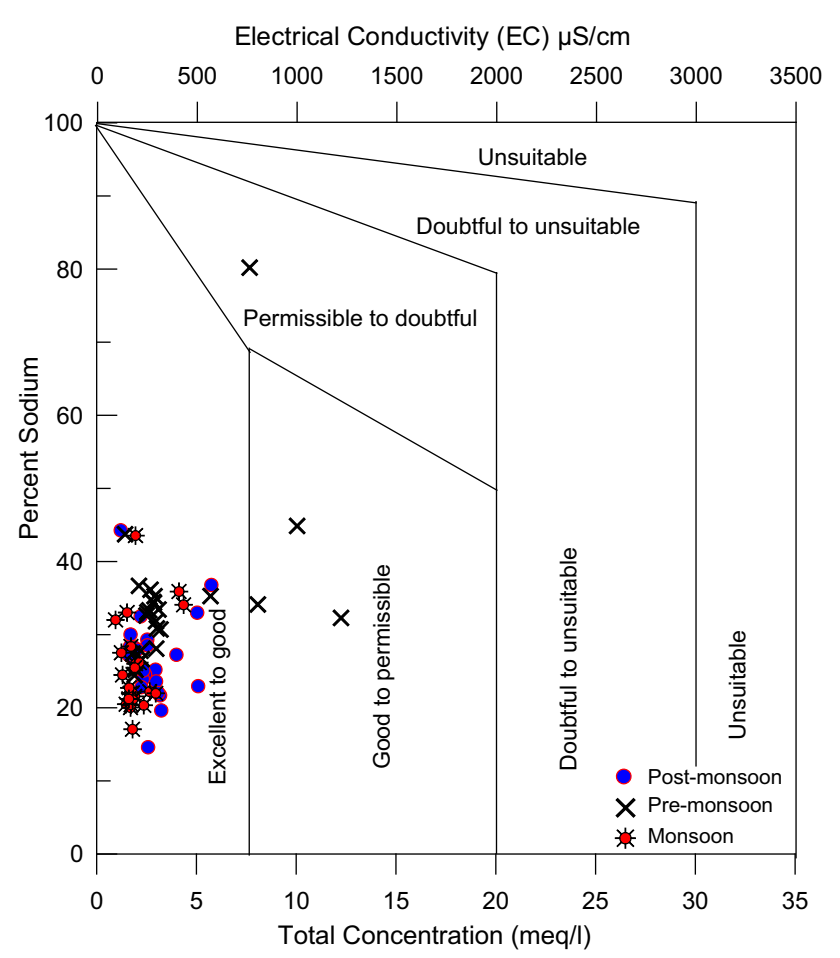

Figure 12. Plot of \% Na vs. EC (after Wilcox 1955).

excellent to good and good to permissible categories for irrigation uses (figure 12).

The relative abundance of alkaline earths $\left(\mathrm{Ca}^{2+}\right.$ $+\mathrm{Mg}^{2+}$ ) with respect to bicarbonate and carbonate also influences the suitability of water for irrigation uses. The excess of carbonates $\left(\mathrm{CO}_{3}^{2-}+\mathrm{HCO}_{3}^{-}\right)$ over alkaline earths $\left(\mathrm{Ca}^{2+}+\mathrm{Mg}^{2+}\right)$ in irrigation water may cause the complete precipitation of $\mathrm{Ca}$ and $\mathrm{Mg}$ as carbonates (Karanth 1989). The water with high RSC has high $\mathrm{pH}$ and land irrigated with such water becomes infertile owing to the deposition of sodium carbonate (Eaton 1950). Irrigation waters having $\mathrm{RSC}$ values $>5$ meq $\mathrm{l}^{-1}$ have been considered harmful to the growth of plants, while waters with RSC values above $2.5 \mathrm{meq}^{-1}$ are unsuitable for irrigation. A RSC value between 1.25 and $2.5 \mathrm{meq}^{-1}$ is considered as the marginal quality and value $<1.25 \mathrm{meq}^{-1}$ as the safe limit for irrigation. The calculated RSC values in most of the analysed water samples are $<2.5$ meq $^{-1}$, suggesting marginal to safe quality of the Subarnarekha River water for irrigation use (table 1).

\section{Conclusion}

The hydro-geochemical study of the Subarnarekha River basin has been carried out to evaluate the major-ion chemistry, solute acquisition processes, dissolved fluxes and suitability of river water for irrigation uses. The analytical result shows that the Subarnarekha water is alkaline in nature like other major Indian rivers. $\mathrm{Ca}^{2+}$ and $\mathrm{Na}^{+}$were the dominant cations, while $\mathrm{HCO}_{3}^{-}$and $\mathrm{Cl}^{-}$dominate in the anion chemistry of the Subarnarekha River water. Seasonality in the ionic concentration is related to the rainfall dilution and river flow regime. Increase in TDS and ionic concentrations during the premonsoon season may be attributed to enhancement in groundwater contribution during the low flow regime of summer months. The Subarnarekha River water chemistry is largely controlled by weathering of rocks with minor contribution from the atmospheric and anthropogenic sources. The high concentration of $\mathrm{HCO}_{3}^{-}$and $\left(\mathrm{Ca}^{2+}+\mathrm{Mg}^{2+}\right)$ and observed $\mathrm{Ca}^{2+} / \mathrm{Na}^{+}, \mathrm{Mg}^{2+} / \mathrm{Na}^{+}, \mathrm{HCO}_{3}^{-} / \mathrm{Na}^{+}$ and $\mathrm{HCO}_{3}^{-} / \mathrm{SiO}_{2}$ ratios suggest that the majorion chemistry of the Subarnarekha River is essentially controlled by two-component mixing from the dissolution of silicates and carbonates. The high concentration of dissolved silica, low ratio of $\left(\mathrm{Ca}^{2+}+\mathrm{Mg}^{2+}\right) /\left(\mathrm{Na}^{+}+\mathrm{K}^{+}\right)$and high $\left(\mathrm{Na}^{+}+\mathrm{K}^{+}\right) / \mathrm{TZ}^{+}$ratio suggest significant contribution of dissolved ions from the silicate weathering. The water chemistry is largely undersaturated with respect to calcite and dolomite; however, most of the pre-monsoon water samples are supersaturated with respect to both. The supersaturation condition in pre-monsoon may be attributed to evaporation effects during the lean water level period which causes preferential extraction of $\mathrm{Ca}$ by precipitation. The chemical behaviour of the river water in the silicate systems demonstrates kaolinite as the possible mineral that is in equilibrium with the water. The Subarnarekha River annually delivered $1.477 \times 10^{6}$ ton of dissolved loads to the Bay of Bengal and the estimated chemical denudation rate of the catchment is 77 ton $\mathrm{km}^{-2} \mathrm{yr}^{-1}$. The annual solute fluxes of the tributaries varied from a minimum of $0.016 \times 10^{6}$ ton (Sankh) to a maximum of $1.023 \times 10^{6}$ ton (Kharkai). The calculated parameters of SAR, $\% \mathrm{Na}$ and RSC show that the Subarnarekha River water is of the 'excellent to good' category for irrigation and can be used to irrigate all soils for tolerant, semi-tolerant and sensitive crops.

\section{Acknowledgements}

Dr. Soma Giri is grateful to the Department of Science and Technology, Government of India for 
funding under Fast Track Young Scientist Scheme (Grant No. SR/FTP/ES-185/2010(G)). Authors are thankful to Dr. P K Singh, Director, CSIRCIMFR for providing the laboratory and other infrastructural facilities and lab colleagues for their help during the study.

\section{References}

Abbas N and Subramanian V 1984 Erosion and sediment transport in the Ganga River basin India; J. Hydrol. 69 173-182.

APHA 1998 Standard methods for the examination of water and waste water; 20th edn, American Public Health Association, Washington DC.

Appelo C A J and Postma D 1996 Geochemistry, groundwater and pollution; AA Balkema Publication, Rotterdam.

Berner E K and Berner R A 1987 The global water cycle: Geochemistry and environment; Prentice-Hall, Englewood Cliffs, NJ.

Berner E K and Berner R A 1996 Global environmental: Water, air and geochemical cycles; Prentice-Hall, New Jersey.

Biksham G and Subramanian V 1988 Nature of solute transport in the Godavari basin, India; J. Hydrol. 103 375392.

Binet S, Spadini L, Bertrand C, Guglielmi Y, Mudry J and Scavia C 2009 Variability of the groundwater sulfate concentration in fractured rock slopes: A tool to identify active unstable areas; Hydrol. Earth Syst. Sci. 13 23152327.

Brennan S K and Lowenstein T K 2002 The major ion composition of Silurian seawater; Geochim. Cosmochim. Acta 66 2683-2700.

Carbonnel J P and Meybeck M 1975 Quality variations of the Mekong River at Phnom Penh, Combodia and chemical transport in the Mekong basin; J. Hydrol. 27249 265.

CBPCWP 1986 Assessment and development study of river basin series ADSORBS/15/1985-86. Basin sub basin inventory of water pollution: The Subarnarekha River basin; Central Board for the Prevention and Control of Water Pollution (CBPCWP), New Delhi.

Chakrapani G J and Subramanian V 1990 Preliminary studies on the geochemistry of the Mahanadi river basin, India; Chem. Geol. 81 241-243.

Chen J, Wang F, Xia X and Zhang L 2002 Major element chemistry of the Changjiang (Yangtze river); Chem. Geol. 187 231-255.

Das B K and Dhiman S C 2003 Water and sediment chemistry of higher Himalayan lakes in the Spiti valley: Control of weathering, provenance and tectonic setting of the basin; Environ. Geol. 44 717-730.

Das A, Krishnaswami S, Sarin M M and Pande K 2005 Chemical weathering in the Krishna Basin and Western Ghats of the Deccan Traps, India: Rate of basalt weathering and their controls; Geochim. Cosmochim. Acta 69 2067-2084.

Drever J I 1988 The geochemistry of natural waters; 2nd edn, Prentice-Hall, Englewood Cliffs.
Eaton F M 1950 Significance of carbonates in irrigation waters; Soil Sci. 39 123-133.

Gaillardet J, Dupre B, Allegre C J and Negrel P 1997 Chemical and physical denudation in the Amazon River Basin; Chem. Geol. 142 141-173.

Gaillardet J, Dupre B, Louvat P and Allegre C J 1999 Global silicate weathering and $\mathrm{CO}_{2}$ consumption rates deduced from the chemistry of large rivers; Chem. Geol. 159 3-30.

Galy A and France-Lanord C 1999 Weathering processes in the Ganges-Brahmaputra basin and the riverine alkalinity budget; Chem. Geol. 159 31-60.

Garrels R M and Christ C L 1965 Solutions, minerals and equilibria; Harper and Row, New York.

Garrels R M and Mackenzie F T 1967 Origin of the chemical compositions of some springs and lakes; In: Equilibrium concepts in natural water systems (ed.) Stumm W, J. Am. Chem. Soc., pp 222-242.

Gibbs R J 1970 Mechanisms controlling world water chemistry; Science 17 1088-1090.

Gibbs R J 1972 Water chemistry of Amazon River; Geochim. Cosmochim. Acta 36 1061-1066.

Gupta L P and Subramanian V 1994 Environmental geochemistry of the River Gomti: A tributary of the Ganges River; Environ. Geol. 24 235-243.

Hardie L A and Eugster H P 1970 The evolution of closedbasin brines; Mineral. Soc. Am. Special Paper 3 273290.

Hounslow A W 1995 Water quality data: Analysis and interpretation; CRC Lewis Publishers, New York, USA.

Hu Ming-Hui, Stallard R F and Edmond J M 1982 Major ion chemistry of the some large Chinese rivers; Nature 298 550-553.

Jha P K, Tiwari J, Singh U K, Kumar M and Subramanian V 2009 Chemical weathering and associated $\mathrm{CO}_{2}$ consumption in the Godavari river basin, India; Chem. Geol. 264 364-374.

Karanth K R 1989 Groundwater assessment development and management; Tata McGraw-Hill Publ, New Delhi.

Krishnaswami S and Singh S K 2005 Chemical weathering in the river basins of the Himalaya, India; Curr. Sci. $\mathbf{8 9}$ 841-849.

Kumar R, Singh R D and Sharma K G 2005 Water resources of India; Curr. Sci. 89 794-811.

Lecomte K L, Pasquini A I and Depetris P J 2005 Mineral weathering in a semiarid mountain River: Its assessment through PHREEQC inverse modelling; Aquatic Geochem. 11 173-194.

Maharana C, Gautam S, Singh A K and Tripathi J K 2015 Major ion chemistry of the Son River, India: Weathering processes dissolve fluxes and water quality assessment; $J$. Earth Syst. Sci. 124 1293-1309.

Meybeck M 1987 Global chemical weathering of surficial rocks estimated from river dissolved loads; $A m$. J. Sci. 287 401-428.

Meybeck M 2003 Global analysis of river systems: From earth system controls to anthropogenic controls; Phil. Trans. $R$. Acad. Lond. B 358 1935-1955.

Nemeth A, Paolini J and Herrera R 1982 Carbon transport in the Orinoco River: The preliminary results; In: Transport of carbon and minerals in the major world rivers (ed.) Degens E T, SCOPE/UNEP Sonderband Heft 52 357364 . 
Pandey K, Sarin M M, Trivedi J R, Krishnaswami S and Sharma K K 1994 The Indus River system (IndiaPakistan): Major ion chemistry, uranium and strontium isotopes; Chem. Geol. 116 245-259.

Parkhurst D L and Appelo C A J 1999 User's guide to PHREEQC (ver. 2) - A computer program for speciation, batch-reaction, one-dimensional transport, and inverse geochemical calculations; US Geol. Surv. Water Resources Investigations Report.

Pattanaik J K, Balakrishnan S, Bhutani R and Singh P 2013 Estimation of weathering rates and $\mathrm{CO}_{2}$ drawdown based on solute load: Significance of granulites and gneisses dominated weathering in the Kaveri River basin, Southern India; Geochim. Cosmochim. Acta 121 611-636.

Piper A 1944 A graphical procedure in the geochemical interpretation of water analysis; Am. Geophys. Union Trans. 25 914-928.

Presley B J, Trefry J H and Shohes R F 1980 Heavy metal inputs to Mississippi delta sediments; Water. Air Soil Pollut. 13 481-494.

Rajamani V, Tripathi J K and Malviya V P 2009 Weathering of lower crustal rocks in the Kaveri River catchment southern India: Implication to sediment geochemistry; Chem. Geol. 265 410-419.

Ramanathan A L, Vaithiyanathan P, Subramanian V and Das B K 1994 Nature and transport of solute load in the Cauvery river basin, India; Wat. Res. 28 15851593.

Ramesh R and Subramanian V 1988 Nature of dissolved loads of the Krishna river basin, India; J. Hydrol. 103 139-155.

Rao K L 1975 India's water wealth, its assessment, uses and projection; Orient Longman, New Delhi.

Reeder S W, Hitchon B and Levinson A A 1972 Hydrogeochemistry of the surface waters of the Mackenzie drainage basin, Canada: Factor controlling inorganic composition; Geochim. Casmochim. Acta 36 825-865.

Richey J E, Hedges J I, Devol A H, Quay P D and Victoria R 1990 Biogeochemistry of carbon in the Amazon River; Limnol. Oceanogr. 35 352-371.

Sarin M M, Krishnaswamy S, Dilli K, Somayajulu B L K and Moore W S 1989 Major ion chemistry of the Ganga-Brahmaputra river system: Weathering processes and fluxes to the Bay of Bengal; Geochim. Cosmochim. Acta 53 997-1009.

Sharma A, Singh A K and Kumar K 2012 Environmental geochemistry and quality assessment of surface and subsurface water of Mahi River basin, India; Environ. Earth Sci. 65 1231-1250.
Singh A K and Hasnain S I 1999 Environmental geochemistry of Damodar river basin - east coast of India; Environ. Geol. 37 124-136.

Singh A K, Mondal G C, Singh P K, Singh S, Singh T B and Tewary B K 2005 Hydrochemistry of reservoirs of Damodar River basin, India: Weathering processes and water quality assessment; Environ. Geol. 8 1014-1028.

Singh A K, Mondal G C, Kumar S, Singh T B, Tewary B K and Sinha A 2008 Major ion chemistry, weathering processes and water quality assessment in upper catchment of Damodar River basin, India; Environ. Geol. 54 745-758.

Stallard R F and Edmond J M 1983 Geochemistry of the Amazon: 2. The influence of the geology and weathering environment on the dissolved load; J. Geophys. Res. $\mathbf{8 8}$ 9671-9688.

Stallard R F and Edmond J M 1987 Geochemistry of the Amazon: 3. Weathering chemistry and limits to dissolved inputs; J. Geophys. Res. 92 8293-8302.

Stott R E and Burt T P 1997 Potassium chemistry of a small upland stream following a major drought; Hydrol. Process. 11 189-201.

Stumm W and Morgan J J 1981 Aquatic chemistry; Wiley Interscience, New York.

Subramanian V 1983 Factors controlling the chemical composition of rivers of India; In: Proceedings of the Hamburg Symposium, IAHS Publ. 141 145-151.

Subramanian V 2000 Water: Quantity-quality perspective in South Asia; Kingston International Publishers, Surrey.

Taylor S R and McLennan S M 1985 The continental crust: Its composition and evolution; Blackwell, London.

Tiwari A K and Singh A K 2014 Hydrogeochemical investigation and groundwater quality assessment of Pratapgarh district, Uttar Pradesh; J. Geol. Soc. India 83 329-343.

USSL (US Salinity Laboratory) 1954 Diagnosis and improvement of saline and alkali soils; U.S. Department of Agriculture Hand Book, No. 60, p. 160.

Viers J, Dupre B, Braunj J, Freydier R, Greenberg S, Ngoupayou J N and Nkamdjou L S 2001 Evidence for non-conservative behavior of chlorine in humid tropical environments; Aquatic Geochem. 7 127-154.

Wilcox L V 1955 Classification and use of irrigation waters; US Dept. of Agricul., Cir. 969, Washington DC.

Zhang J, Haung R, Jiu M G and Zhou Q 1990 Drainage basin weathering and major element transport of two large Chinese rivers (Huanghe and Changjiang); J. Geophys. Res. 95 13277-13288.

Zhang J, Huang W W, Letolle R and Jusserand C 1995 Major element chemistry of the Huanghe (Yellow river), China - Weathering processes and chemical fluxes; $J$. Hydrol. 168 173-203. 